Review

\title{
Drug Repurposing Opportunities in Pancreatic Ductal Adenocarcinoma
}

\author{
Rita Rebelo ${ }^{1,2,+} \mathbb{D}^{D}$, Bárbara Polónia ${ }^{1,2,+}$, Lúcio Lara Santos ${ }^{3,4}$, M. Helena Vasconcelos ${ }^{1,2,5, *(\mathbb{D})}$ and \\ Cristina P. R. Xavier 1,2,5,*(D)
}

1 Cancer Drug Resistance Group, IPATIMUP - Institute of Molecular Pathology and Immunology, University of Porto, 4200-135 Porto, Portugal; rrebelo@ipatimup.pt (R.R.); bpolonia@i3S.up.pt (B.P.)

2 i3S-Instituto de Investigação e Inovação em Saúde, Universidade do Porto, 4200-135 Porto, Portugal

3 Experimental Pathology and Therapeutics Group, IPO—Instituto Português de Oncologia, 4200-072 Porto, Portugal; 1larasantos@gmail.com

4 ICBAS-Biomedical Sciences Institute Abel Salazar, Universidade do Porto, 4050-313 Porto, Portugal

5 Department of Biological Sciences, FFUP-Faculty of Pharmacy of the University of Porto, 4200-135 Porto, Portugal

* Correspondence: hvasconcelos@ipatimup.pt (M.H.V.); cristinax@ipatimup.pt (C.P.R.X.)

+ These authors equally contributed to this work.

check for updates

Citation: Rebelo, R.; Polónia, B.; Santos, L.L.; Vasconcelos, M.H.; Xavier, C.P.R. Drug Repurposing Opportunities in Pancreatic Ductal Adenocarcinoma. Pharmaceuticals 2021, 14, 280. https://doi.org/ $10.3390 /$ ph14030280

Academic Editor: Mary Meegan

Received: 24 February 2021

Accepted: 17 March 2021

Published: 20 March 2021

Publisher's Note: MDPI stays neutral with regard to jurisdictional claims in published maps and institutional affiliations.

Copyright: (c) 2021 by the authors. Licensee MDPI, Basel, Switzerland. This article is an open access article distributed under the terms and conditions of the Creative Commons Attribution (CC BY) license (https:// creativecommons.org/licenses/by/ $4.0 /)$.

\begin{abstract}
Pancreatic ductal adenocarcinoma (PDAC) is considered one of the deadliest tumors worldwide. The diagnosis is often possible only in the latter stages of the disease, with patients already presenting an advanced or metastatic tumor. It is also one of the cancers with poorest prognosis, presenting a five-year survival rate of around 5\%. Treatment of PDAC is still a major challenge, with cytotoxic chemotherapy remaining the basis of systemic therapy. However, no major advances have been made recently, and therapeutic options are limited and highly toxic. Thus, novel therapeutic options are urgently needed. Drug repurposing is a strategy for the development of novel treatments using approved or investigational drugs outside the scope of the original clinical indication. Since repurposed drugs have already completed several stages of the drug development process, a broad range of data is already available. Thus, when compared with de novo drug development, drug repurposing is time-efficient, inexpensive and has less risk of failure in future clinical trials. Several repurposing candidates have been investigated in the past years for the treatment of PDAC, as single agents or in combination with conventional chemotherapy. This review gives an overview of the main drugs that have been investigated as repurposing candidates, for the potential treatment of PDAC, in preclinical studies and clinical trials.
\end{abstract}

Keywords: drug repurposing; pharmacology; pancreatic cancer; therapeutic strategies

\section{Drug Repurposing: An Attractive and Challenging Approach}

Drug repurposing has been emerging as an interesting alternative to the conventional drug discovery process. Additionally referred to as "drug repositioning", "drug reprofiling", "drug redirecting", "drug rediscovery" or "drug re-tasking", this is a strategy for the development of novel treatments using approved or investigational drugs outside the scope of the original clinical indication [1-3]. Interestingly, the recent development and increasing interest observed in genomic and proteomic technologies for the assessment of cancer specific biological pathways has led to the discovery of several new drug targets, providing excellent opportunities for drug repurposing, since almost every drug used in human therapy has the potential to address more than one target [3]. The increasing interest in this approach relies on the fact that, by finding new applications for clinically approved drugs, drug repurposing is able to overcome the major issues associated with conventional drug discovery, which include substantial costs, slow pace and high risk of failure [3,4]. According to Nosengo (2016), the estimated cost for a repurposed drug to reach the market is US\$300 million, whereas, for a new drug, it is estimated to be $\sim 2$ to $\$ 3$ 
billion [5]. Interestingly, the Food and Drug Administration (FDA) approval for new drugs has decreased in the past years, especially when compared to the 1990s [6].

In fact, clinically approved drugs have previously completed several stages of the drug development process; hence, data regarding dosing, safety, toxicity, drug interactions, side effects, pharmacodynamics and pharmacokinetics is often available [1-3]. Therefore, the need for large investments and the time frame for drug development can be significantly reduced $[1,3]$. As depicted in Figure 1, while new drug discovery and development might take up to 10 to 17 years for a drug to reach the market, the timeline for drug repurposing is only about 3 to 12 years [4]. Additionally, the previous evidence on the effect of these drugs in preclinical models and in humans reduces the risk of failure in upcoming clinical trials [1]. Nevertheless, despite its great advantages, drug repurposing can face several obstacles, particularly in drug licensing, clinical adoption or even during the development of clinical trials [1,2]. These problems might be explained by the existence of regulatory exclusivities, which increase drug market protection beyond the patent term, or by drug withdrawal from the market, which hampers drug supply for clinical trials, as well as by complications in the label extension in medicines that are authorized through national procedures $[1,2]$.

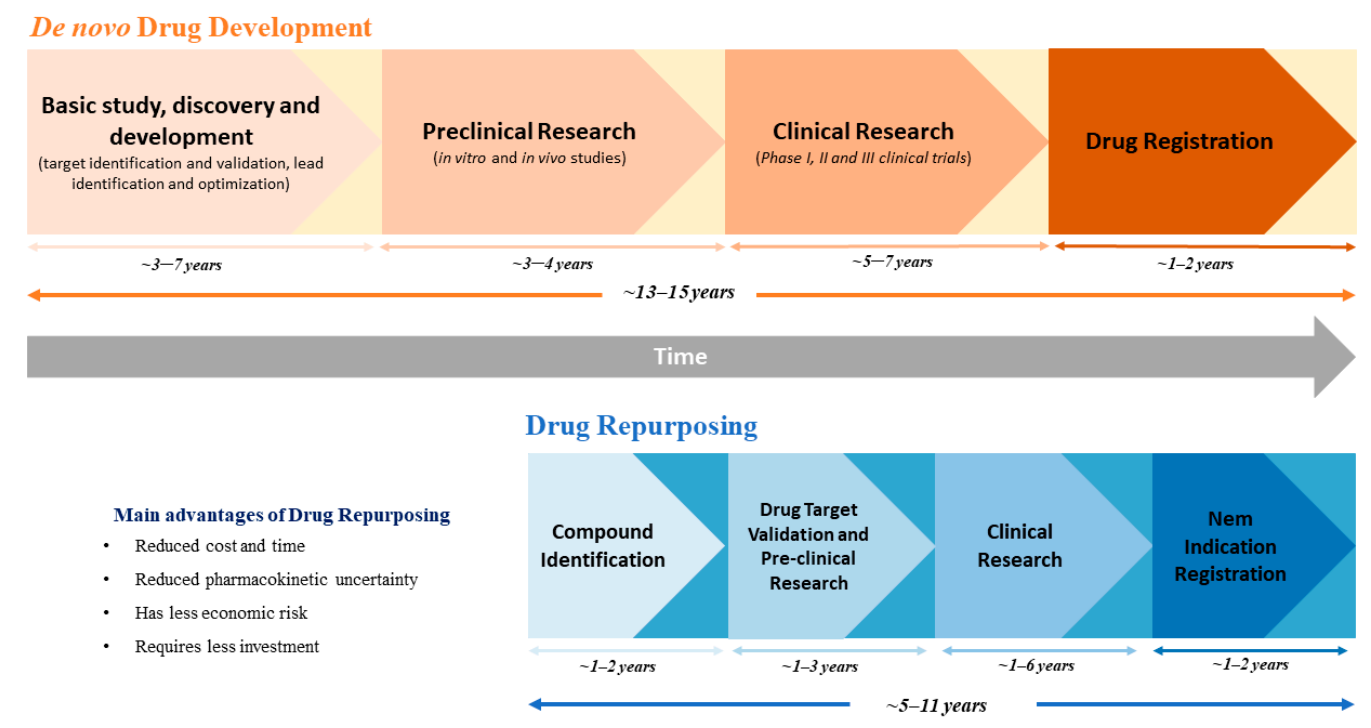

Figure 1. Schematic comparison between the processes and timeline of de novo drug development and drug repurposing.

Nonetheless, drug repurposing represents a relatively unexplored source of new therapies, being a very attractive option, especially in neglected areas of medicine, where the lack of commercial interest delays drug development. Moreover, drug repurposing candidates that are off-patent offer an additional advantage. The competitive environment in the pharmaceutical industry leads to a severe markdown in their prices, which facilitates access to medicines for the general population and reduces the public health burden [2].

Initially, drug repurposing was largely a serendipitous process or was based on clinical side effects and off-label use [1,3]. One of the first cases of drug repurposing was thalidomide, a sedative and antiemetic drug that was found to be effective in the treatment of erythema nodosum leprosum and, later, in multiple myeloma. This led to the development of analogs, such as lenalidomide and pomalidomide, which are nowadays successfully used in the treatment of multiple myeloma [1]. Other popular cases resulted from different repurposing approaches, such as a retrospective clinical analysis or pharmacological analysis $[1,3]$. Most recently, systematic approaches have been employed to identify novel candidates for drug repurposing, namely computational (molecular docking, pathway mapping, genetic association, signature matching, etc.) and experimental ones (binding assays and phenotypic screening) [1]. 
Despite the great advances in technology and the growing knowledge of cancer, the oncological field still faces serious challenges, including the limited success of current therapies and the decline in new oncology drugs approval, along with the increasing incidence of cancer and the lack of treatments for rare cancers [6-9]. Therefore, drug repurposing could respond to some of the existing unmet needs in this field. In fact, several drugs have already been successfully repurposed in the cancer field. Some examples are listed in Table 1.

For instance, the chemotherapeutic drug gemcitabine was initially designed as an antiviral drug but, afterwards, was found to have antitumor activity in vivo [10]. Nowadays, gemcitabine is used to treat a wide variety of cancers, being the gold standard chemotherapeutic drug in pancreatic cancer [11].

Table 1. Successful examples of drug repurposing in cancer treatment.

\begin{tabular}{|c|c|c|c|c|c|}
\hline Drug & $\begin{array}{l}\text { Original } \\
\text { Indication }\end{array}$ & $\begin{array}{c}\text { New Clinical Indication in } \\
\text { Cancer Treatment }\end{array}$ & $\begin{array}{l}\text { Date of } \\
\text { Approval }\end{array}$ & Mechanism of Action & References \\
\hline $\begin{array}{l}\text { Retinoic } \\
\text { acid/Tretinoin }\end{array}$ & Acne & $\begin{array}{c}\text { Acute promyelocytic } \\
\text { leukemia }\end{array}$ & 1996 & $\begin{array}{c}\text { Binds to retinoic acid receptors and } \\
\text { degrades the fusion protein } \\
\text { PML-RARa }\end{array}$ & {$[12]$} \\
\hline Interferon $\alpha 2 b$ & Hepatitis B and C & $\begin{array}{l}\text { Melanoma, Multiple } \\
\text { myeloma, Hairy cell } \\
\text { leukemia, Carcinoid tumor, } \\
\text { Follicular lymphoma }\end{array}$ & 2000 & Immunomodulatory activity & {$[13]$} \\
\hline Thalidomide & $\begin{array}{l}\text { Sedative/anti- } \\
\text { emetic }\end{array}$ & Multiple myeloma & 2006 & $\begin{array}{l}\text { Immunomodulatory, } \\
\text { anti-inflammatory and potential } \\
\text { anti-neoplastic activities due to } \\
\text { inhibition of tumor necrosis } \\
\text { factor-alpha (TNF- } \alpha \text { ) production }\end{array}$ & {$[14]$} \\
\hline Raloxifene & Osteoporosis & Breast cancer & 2007 & $\begin{array}{l}\text { Selective estrogen receptor modulator } \\
\text { (SERM) that acts like an antagonist in } \\
\text { uterine and breast tissues }\end{array}$ & {$[15]$} \\
\hline Gemcitabine & Antiviral & $\begin{array}{l}\text { Bladder cancer; Pancreatic } \\
\text { ductal adenocarcinoma; } \\
\text { Non-small cell lung cancer; } \\
\text { Ovarian cancer; Breast cancer }\end{array}$ & 2009 & $\begin{array}{l}\text { Pyrimidine antimetabolite inhibits } \\
\text { DNA synthesis, leading to apoptosis } \\
\text { and arresting tumor growth }\end{array}$ & {$[16]$} \\
\hline Pomalidomide & $\begin{array}{l}\text { Thalidomide } \\
\text { derivative }\end{array}$ & Multiple myeloma & 2013 & $\begin{array}{l}\text { Cytotoxic and immunomodulatory } \\
\text { effects. Suppresses angiogenesis by } \\
\text { blocking the migration and adhesion } \\
\text { of endothelial cells }\end{array}$ & {$[17]$} \\
\hline Itraconazole & Antifungal & $\begin{array}{l}\text { Nevoid basal-cell carcinoma } \\
\text { (Gorlin syndrome) }\end{array}$ & 2017 & $\begin{array}{l}\text { Binds to Smoothened (SMO) protein, } \\
\text { blocking the Hedgehog signaling } \\
\text { pathway and limiting the growth and } \\
\text { spread of tumoral cells }\end{array}$ & {$[18]$} \\
\hline Lenalidomide & $\begin{array}{l}\text { Thalidomide } \\
\text { derivative }\end{array}$ & Multiple myeloma & 2018 & $\begin{array}{l}\text { Cytotoxic and immunomodulatory } \\
\text { effects due to the degradation of } \\
\text { lymphoid transcriptional factors }\end{array}$ & [19] \\
\hline Arsenic & $\begin{array}{l}\text { Tuberculosis and } \\
\text { syphilis }\end{array}$ & $\begin{array}{c}\text { Acute promyelocytic } \\
\text { leukemia }\end{array}$ & 2020 & $\begin{array}{c}\text { Causes fragmentation of DNA and } \\
\text { degrades the fusion protein } \\
\text { PML-RARa }\end{array}$ & {$[20]$} \\
\hline
\end{tabular}

As highlighted in the next section, pancreatic cancer is a very challenging disease. The difficult early diagnosis and lack of effective therapies creates an urgency for new therapeutic options to treat this high-mortality malignancy. Therefore, drug repurposing emerges as a resourceful strategy to accelerate the discovery of novel and effective treatments, with a rapid clinical translation. This review focuses on the current panorama of pancreatic cancer and summarizes the most recent studies on potential drug repurposing candidates for the treatment of this disease. 


\section{Pancreatic Cancer: The Current Picture}

According to Global Cancer Observatory, in 2018, pancreatic cancer was considered the seventh deadliest cancer worldwide, despite being only the 12th with most incidence, and its mortality is estimated to increase up to $~ 80 \%$ by 2040 [21]. With a five-year survival rate of approximately $5 \%$, pancreatic cancer is one of the cancers with the poorest prognosis, and no major advances in cancer treatments have been done in the past 20 years [11,22]. Mortality and incidence rates have not improved in the last decades [23]. Therefore, new strategies of drug development need to be implemented.

Pancreatic cancer affects mainly the elderly population [24]. The vast majority of patients are diagnosed at late stages, already presenting a metastatic or locally advance disease, which hampers surgical excision [11,25]. Only around $10 \%$ of pancreatic carcinomas are caused by inherited germlines mutations, the majority of cases due to nongenetic risk factors, such as chronic pancreatitis and diabetes (nonmodifiable factors), smoking, obesity, diet and alcohol abuse (modifiable factors) $[11,26]$. Infections caused by Helicobacter pylori, hepatitis B and human immunodeficiency virus also appear to increase the relative risk of pancreatic cancer [11].

Pancreatic cancer can develop from both exocrine and endocrine cells; however, exocrine tumors represent approximately $95 \%$ of all cases (with only $2 \%$ of these being benign), while the remaining 5\% corresponds to endocrine tumors, often known as Pancreatic Neuroendocrine Tumors (pNETs) [11]. The most common type is Pancreatic Ductal Adenocarcinoma (PDAC), which accounts for approximately $85 \%$ of all pancreatic cancers; thus, it is usually referred to as "pancreatic cancer" [11,26-30]. For this reason, our review will focus on this type of pancreatic cancer.

PDAC follows the adenoma-to-carcinoma model, presenting a stepwise evolution from noninvasive preneoplastic lesions to invasive tumors [11,24,26,30-32]. Intraepithelial neoplasms (PanINs) are the most frequent precursor lesions and commonly harbor mutations in KRAS, CDKN2A, TP53 and SMAD4 genes [33-36]. However, recent wholegenome sequencing studies are challenging this model, suggesting that the simultaneous impairment of these genes might occur in some cases, possibly through chromothripsis, rather than the sequential accumulation of mutations by precursor lesions [37]. Nonetheless, it is well-known that more than $90 \%$ of pancreatic cancers harbor a KRAS mutation and that silencing mutations in tumor-suppressor genes, especially in CDKN2A (80-95\%), TP53 (50-70\%) and SMAD4 (>50\%), can simultaneously occur [11,26,38,39]. Additionally, somatic aberrations in DNA mismatch repair genes, like $M L H 1$ and $M S H 2$, may also be found [11].

As aforementioned, PDAC remains a very difficult disease to treat, and several factors can be accountable for this failure. First, early detection is extremely difficult, since PDAC is often asymptomatic until reaching an advanced or metastatic sate [26]. The second issue is the lack of an accurate and inexpensive screening method for the general population [26]. Unfortunately, surgical resection is only possible in $15-20 \%$ of patients, and the five-year survival rate is approximately $20 \%[11,40]$. In addition, the local and systemic recurrence rates after resection are relatively high, reaching up to $60 \%$ and $90 \%$ of cases, respectively [38,41]. Unfortunately, the majority of PDAC patients are not even eligible for surgery, and cytotoxic chemotherapy remains the basis of systemic therapy. In patients with borderline resectable tumors, chemotherapy is used as a neoadjuvant therapy, and in patients with locally advanced or metastatic tumors, it is used to reduce disease burden or as a palliative treatment, respectively $[38,41]$. However, no major advances have been made regarding PDAC treatment; thus, few therapeutic options are available, and these are highly toxic to patients. The most frequently used drugs in chemotherapy regimens for PDAC treatment include gemcitabine, FOLFIRINOX (leucovorin/5-fluorouracil/irinotecan/oxaliplatin), nab-paclitaxel, erlotinib, capecitabine, GTX (gemcitabine/docetaxel/capecitabine) and irinotecan [42]. In addition, the combinatory treatment of gemcitabine with cisplatin is used in tumors with BRCA1/2 mutations, whereas pembrolizumab is used as a second-line therapy in tumors with Microsatellite Instability-High or deficient Mismatch Repair [42]. 
In the last decade, there were two major improvements in the current standard care of metastatic PDAC. First, in 2013, the combination of gemcitabine and nab-paclitaxel was approved for the first-line treatment of patients with metastatic PDAC, following the report from Von Hoff et al. showing that this combination could improve the overall survival, progression-free survival and response rate compared to gemcitabine alone, although it presented an increased toxicity $[11,43,44]$. More recently, in 2016, a phase III trial conducted by Wang-Gilam et al. demonstrated that nanoliposomal irinotecan could extend the overall survival in combination with 5-fluorouracil (5-FU)/leucovorin in patients with metastatic PDAC who progressed after gemcitabine treatment, with a manageable safety profile [45]. Therefore, the FDA and European Medicines Agency (EMA) have approved this new treatment as a second-line regimen [46].

Finally, another obstacle in pancreatic cancer treatment is its unique tumor microenvironment (TME), which is composed of extracellular matrix, cancer cells and stromal cells, including pancreatic stellate cells (PSCs), fibroblasts, myeloid-derived suppressor cells (MDSCs), regulatory T cells (Tregs) and tumor-associated macrophages (TAMs) [47,48]. When activated by cancer cells, PSCs produce stromal components, such as laminin, fibronectin and collagens, a process known as desmoplasia that is found both in primary and metastatic PDAC tumors [47-52]. Studies show that, although stroma's primary function would be to restrain tumor growth, angiogenesis and metastization, there is a reprogramming of stromal cells by cancer cells to support tumorigenesis $[48,53,54]$. This results in an intense stromal reaction that acts like a mechanical barrier around the tumor and hampers the appropriate vascularization, limiting immune cell infiltration and drug delivery [11,55]. Given the complexity of the stroma in PDAC and the high heterogeneity of the cellular populations that comprised it, stroma-targeted therapies might exert divergent effects; therefore, this type of therapy should be carefully evaluated in this type of cancer $[48,56]$.

\section{Drug Repurposing Candidates for Pancreatic Cancer Treatment}

In the past years, several studies have been investigating the potential of drug repurposing candidates for the treatment of pancreatic cancer, as single agents or in combination with conventional chemotherapy. These candidates target multiple hallmarks of cancer (replicative immortality, resistance to cell death, deregulated metabolism, sustained angiogenesis and evasion to the immune system, tissue invasion and metastasis,) and belong to very different pharmacological classes, from antibiotics to antipsychotics.

As summarized in Table 2, this section highlights several preclinical studies that have been evaluating the potential of selected drug repurposing candidates for the treatment of PDAC, either targeting pancreatic cancer cells or cells from the TME. Nonetheless, many of these candidates still need further studies to confirm their anticancer efficacy. 
Table 2. Selected drug repurposing candidates for treatment of PDAC.

\begin{tabular}{|c|c|c|c|c|c|c|c|c|c|}
\hline \multirow{2}{*}{ Drug } & \multirow{2}{*}{$\begin{array}{l}\text { Pharmacological } \\
\text { Class }\end{array}$} & \multirow{2}{*}{$\begin{array}{l}\text { Original } \\
\text { Indication }\end{array}$} & \multicolumn{3}{|c|}{ Evidence } & \multirow{2}{*}{ Biological Models } & \multirow{2}{*}{ Tested Concentrations } & \multirow{2}{*}{ Described Mechanisms } & \multirow{2}{*}{ References } \\
\hline & & & In Vitro & In Vivo & Clinical & & & & \\
\hline Carglumic acid & $\begin{array}{l}\text { Amino acids and } \\
\text { derivatives }\end{array}$ & Hyperammonemia & + & + & & $\begin{array}{l}\text { Human (AsPC-1 and Capan-1) } \\
\text { and Murine (Pan02) pancreatic } \\
\text { cancer cell lines } \\
\text { - } \quad \text { Human pancreatic ductal } \\
\text { epithelial cell line (HPDE-E6E7) } \\
\text { Orthotopic PDAC mouse } \\
\text { model }\end{array}$ & $\begin{array}{ll}\text { - } & \text { Half maximal } \\
\text { inhibitory } \\
\text { concentration }\left(\mathrm{IC}_{50}\right)= \\
5-7.5 \mathrm{mM} \\
120 \mathrm{mg} / \mathrm{kg} \text { once per } \\
\text { day (o.d)., } 10 \text { days }\end{array}$ & - Induction of apoptosis & [57] \\
\hline Warfarin & Anticoagulant & $\begin{array}{l}\text { Prophylaxis and } \\
\text { treatment of } \\
\text { venous } \\
\text { thrombosis and } \\
\text { thromboembolic } \\
\text { complication }\end{array}$ & + & + & + & $\begin{array}{ll}\text { - } & \text { Human (AsPC-1, Panc-1, } \\
\text { Capan-1, Mia PaCa-2 and } \\
\text { C5LM2) and murine (Pan02) } \\
\text { pancreatic cancer cell lines [58] } \\
\text { - Syngeneic PDAC mouse model } \\
\text { (Pan02) [58] } \\
\text { - } \quad \text { Spontaneous genetic PDAC } \\
\text { mouse model (KIC) [58] } \\
\text { - Human PDAC xenografts } \\
\text { mouse models (Panc-1, AsPC-1, } \\
\text { Capan-1) [58] } \\
\text { - } \quad \text { KIC model [59] } \\
\text { Panc02-SIY mouse model [60] }\end{array}$ & $\begin{array}{ll}- & 1.5-3 \mathrm{mM} \text { [58] } \\
& 0.2 \mathrm{mg} / \mathrm{kg} \text { body } \\
& \text { weight o.d., } 5 \\
& \text { days/week [59] } \\
& 1.25 \mathrm{mg} / \mathrm{L} \text { [60] }\end{array}$ & $\begin{array}{ll}\text { - } & \text { Inhibition of } \\
\text { Gas6-induced Axl } \\
\text { signaling activated } \\
\text { apoptosis and } \\
\text { suppressed EMT } \\
\text { Immunomodulatory } \\
\text { response by inhibition } \\
\text { of MerTK signaling }\end{array}$ & [58-61] \\
\hline Metformin & $\begin{array}{l}\text { Antidiabetic } \\
\text { (Biguanide) }\end{array}$ & $\begin{array}{l}\text { Type } 2 \text { diabetes } \\
\text { mellitus }\end{array}$ & + & + & + & $\begin{array}{l}\text { - Human pancreatic cancer cell } \\
\text { lines (BxPC3, Mia PaCa-2 and } \\
\text { AsPC-1) [62] } \\
\text { - } \quad \text { KC and KPC mice [63] } \\
\text { - } \quad \text { Human pancreatic cancer cell } \\
\text { lines (BxPC3 and Panc-1) [64] } \\
\text { - KPC mice [64] }\end{array}$ & $\begin{array}{ll}- & 250 \mathrm{nM} \text { and } 1 \mathrm{mM} \text { [62] } \\
& 200 \mathrm{mg} / \mathrm{kg} \text { o.d. [63] } \\
& 2 \mathrm{mM} \mathrm{[64]} \\
& 200 \mathrm{mg} / \mathrm{kg} \text { o.d., } 4 \\
& \text { weeks [64] }\end{array}$ & $\begin{array}{ll}\text { - } & \text { Inhibition of mTOR, } \\
\text { STAT3 and } \\
\text { TGF- } \beta 1 / \text { Smad2/3 } \\
\text { signaling } \\
\text { - Activation of AMPK }\end{array}$ & [62-64] \\
\hline Monensin & $\begin{array}{c}\text { Antibiotic } \\
\text { (veterinary use) }\end{array}$ & $\begin{array}{l}\text { Ketosis in } \\
\text { peri-parturient } \\
\text { dairy cow } / \text { heifer }\end{array}$ & + & + & & $\begin{array}{l}\text { Human pancreatic cancer cell } \\
\text { lines (Panc-1 and MiaPaCa-2) }\end{array}$ & - $\quad 0.5-4 \mathrm{mM}$ & $\begin{array}{l}\text { - Activation of apoptosis } \\
\text { and cell cycle arrest } \\
\text { Inhibition of the } \\
\text { E2F/DP1, STAT1/2, } \\
\text { NF-kB, AP-1 and } \\
\text { Elk-1/SRF pathways } \\
\text { and suppression of } \\
\text { EGFR expression }\end{array}$ & [65] \\
\hline
\end{tabular}


Table 2. Cont

\begin{tabular}{|c|c|c|c|c|c|c|c|c|c|}
\hline \multirow{2}{*}{ Drug } & \multirow{2}{*}{$\begin{array}{c}\text { Pharmacological } \\
\text { Class }\end{array}$} & \multirow{2}{*}{$\begin{array}{l}\text { Original } \\
\text { Indication }\end{array}$} & \multicolumn{3}{|c|}{ Evidence } & \multirow{2}{*}{ Biological Models } & \multirow{2}{*}{ Tested Concentrations } & \multirow{2}{*}{ Described Mechanisms } & \multirow{2}{*}{ References } \\
\hline & & & In Vitro & In Vivo & Clinical & & & & \\
\hline $\begin{array}{l}\text { Nelfinavir and } \\
\text { nitroxoline }\end{array}$ & $\begin{array}{l}\text { Antiviral } \\
\text { (Nelfinavir), } \\
\text { Antibiotic } \\
\text { (Nitroxoline) }\end{array}$ & $\begin{array}{l}\text { Nelfinavir: HIV-1 } \\
\text { infection } \\
\text { Nitroxoline: } \\
\text { Urinary tract } \\
\text { infection }\end{array}$ & + & & & $\begin{array}{l}\text { - Human pancreatic cancer cell } \\
\text { lines (AsPC-1, Capan-2 and } \\
\text { BxPC-3) [66] } \\
\text { Human pancreatic cancer cell } \\
\text { line (AsPC-1) [67] }\end{array}$ & $\begin{array}{ll}\text { - } & \text { Nelfinavir: 3-48 mM } \\
& {[66]} \\
\text { - } & \text { Nitroxoline: } 16-40 \mathrm{mM} \\
& {[66] ; 27 \mathrm{mM}[67]}\end{array}$ & $\begin{array}{l}\text { - Cell cycle arrest and } \\
\text { activation of apoptosis } \\
\text { Nitroxoline: ROS } \\
\text { production, DNA } \\
\text { damage response, } \\
\text { mitochondrial } \\
\text { depolarization and } \\
\text { deregulation of } \\
\text { cytosolic iron } \\
\text { homeostasis [67] }\end{array}$ & {$[66,67]$} \\
\hline $\begin{array}{l}\text { Azithromycin, } \\
\text { doxycycline, } \\
\text { tigecycline and } \\
\text { pyrvinium }\end{array}$ & $\begin{array}{l}\text { Antibiotic } \\
\text { (Doxycycline, } \\
\text { Azithromycin, } \\
\text { Tigecycline), } \\
\text { Anthelmintic } \\
\text { (Pyrvinium) }\end{array}$ & $\begin{array}{c}\text { Doxycycline, } \\
\text { Azithromycin, } \\
\text { Tigecycline: } \\
\text { bacterial infections } \\
\text { Pyrvinium: } \\
\text { gastrointestinal } \\
\text { parasitic infections }\end{array}$ & + & + & & $\begin{array}{ll}\text { - } & \text { Human pancreatic cancer cell } \\
\text { line (Panc-1) [68] } \\
\text { - } \quad \text { Human PDAC xenograft } \\
\text { mouse model [68] } \\
\text { - Human pancreatic cancer cell } \\
\text { line (MiaPaca-2) [69] }\end{array}$ & $\begin{array}{ll}\text { - } & \text { Doxycycline: } 10-40 \\
& \mu \mathrm{g} / \mathrm{mL} \text { [68]; } 50 \mu \mathrm{M}[69] \\
\text { - } & \text { Azithromycin: } 250 \mu \mathrm{M} \\
& \text { [69] } \\
\text { - } & \text { Tigecycline: } 50 \mu \mathrm{M} \text { [69] } \\
\text { - } & \text { Pyrvinium: } 250 \mathrm{nM} \\
& \text { and 500 nM [69] }\end{array}$ & $\begin{array}{l}\text { - Induction of apoptosis } \\
\text { and cell cycle arrest } \\
\text { [68] } \\
\text { Impairment of } \\
\text { mitochondrial } \\
\text { biogenesis and } \\
\text { oxidative } \\
\text { phosphorylation [69] }\end{array}$ & {$[68,69]$} \\
\hline Ritonavir & Antiviral & HIV-1 infection & + & + & & $\begin{array}{l}\text { - Human pancreatic cancer cell } \\
\text { lines (BxPC-3, MiaPaCa-2 and } \\
\text { Panc-1) [70] } \\
\text { Genetically engineered PDAC } \\
\text { mice models [71] }\end{array}$ & $\begin{array}{ll}-\quad & 5-30 \mu \mathrm{M}[70] \\
& 125 \mathrm{mg} / \mathrm{kg}, 28 \text { days } \\
& {[71]}\end{array}$ & $\begin{array}{l}\text { Induction of apoptosis } \\
\text { and cell cycle arrest, } \\
\text { through Inhibition of } \\
\text { E2F-1 and AKT } \\
\text { pathway }\end{array}$ & {$[70,71]$} \\
\hline Itraconazole & Antifungal & Fungal infections & + & + & + & $\begin{array}{ll}\text { - } & \text { Human pancreatic cancer cell } \\
\text { - } & \text { KPC (BxPC-3 and Panc-1) [72] } \\
\text { - } & \text { Human pancreatic cancer cell } \\
& \text { lines (Panc-1, CFPAC-1 and } \\
& \text { MiaPaCa-2) [73] } \\
\text { - } & \begin{array}{l}\text { Human PDAC xenograft } \\
\text { mouse model [73] }\end{array}\end{array}$ & $\begin{array}{ll}\bullet & 0.5-10 \mathrm{mM} \mathrm{[72]} \\
\bullet & 5-160 \mathrm{mM} \mathrm{[73]} \\
\bullet & 40 \text { and } 80 \mathrm{mg} / \mathrm{kg}[73]\end{array}$ & $\begin{array}{ll}\text { - } & \text { Activation of apoptosis } \\
\text { Inhibition of } \\
\text { TGF- } \beta / \text { SMAD2/3 } \\
\text { signaling } \\
\text { ROS production and } \\
\text { mitochondrial } \\
\text { membrane } \\
\text { depolarization }\end{array}$ & {$[72,73]$} \\
\hline
\end{tabular}


Table 2. Cont.

\begin{tabular}{|c|c|c|c|c|c|c|c|c|c|}
\hline \multirow{2}{*}{ Drug } & \multirow{2}{*}{$\begin{array}{c}\text { Pharmacological } \\
\text { Class }\end{array}$} & \multirow{2}{*}{$\begin{array}{l}\text { Original } \\
\text { Indication }\end{array}$} & \multicolumn{3}{|c|}{ Evidence } & \multirow{2}{*}{ Biological Models } & \multirow{2}{*}{ Tested Concentrations } & \multirow{2}{*}{ Described Mechanisms } & \multirow{2}{*}{ References } \\
\hline & & & In Vitro & In Vivo & Clinical & & & & \\
\hline Parbendazole & $\begin{array}{c}\text { Anthelmintic } \\
\text { (veterinary use) }\end{array}$ & $\begin{array}{l}\text { Parasitic infections } \\
\text { by nematodes }\end{array}$ & + & & & $\begin{array}{l}\text { Human pancreatic cancer cell } \\
\text { lines (AsPC-1 and Capan-2) }\end{array}$ & - $\quad 0.06-4 \mathrm{mM}$ & $\begin{array}{l}\text { Apoptosis induction, } \\
\text { DNA damage, cell } \\
\text { cycle arrest and } \\
\text { alterations of tubulin } \\
\text { distribution }\end{array}$ & [74] \\
\hline $\begin{array}{l}\text { Verteporfin, } \\
\text { protoporphyrin } \\
\text { IX }\end{array}$ & $\begin{array}{l}\text { Antineovascularization } \\
\text { agent (Verteporfin), } \\
\text { Sensitizers in } \\
\text { photodynamic therapy } \\
\text { (protoporphyrin IX) }\end{array}$ & $\begin{array}{l}\text { Verteporfin: } \\
\text { aged-related } \\
\text { macular } \\
\text { degeneration } \\
\text { Protoporphyrin IX: } \\
\text { visualization of } \\
\text { malignant tissue } \\
\text { for malignant } \\
\text { glioma }\end{array}$ & + & & & $\begin{array}{l}\text { Human (Paca-3, MiaPaca-2, } \\
\text { Panc-1) and mouse (Panc02) } \\
\text { pancreatic cancer cell lines [75] } \\
\text { Normal human pancreatic } \\
\text { ductal epithelial cell line } \\
\text { (HPDE) [75] } \\
\text { Human pancreatic cancer cell } \\
\text { line (BxPC-3) [76] }\end{array}$ & $\begin{array}{ll}\bullet & 2.5 \mu \mathrm{g} / \mathrm{mL}[75] \\
\bullet & 0.1,0.5 \text { and } 1 \mu \mathrm{M}) \\
& {[76]}\end{array}$ & $\begin{array}{ll}\text { - } & \text { Activation of apoptosis } \\
\text { via TAp73 activation, } \\
\text { - } \\
\text { Inhibition of } \\
\text { thioredoxin reductase } \\
\text { - } \quad \begin{array}{l}\text { Inhibition of } \\
\text { Hippo/YAP signaling } \\
\text { pathway }\end{array}\end{array}$ & {$[75,76]$} \\
\hline Penfluridol & Antipsychotic & $\begin{array}{l}\text { Psychological } \\
\text { disorders }\end{array}$ & + & + & & $\begin{array}{l}\text { Human pancreatic cancer cell } \\
\text { lines (MiaPaca-2, Panc-1, } \\
\text { SU8686, Panc0504, Panc0403, } \\
\text { Panc1005, Panc0203, Panc0327, } \\
\text { AsPc1 and BxPc-3) [77] } \\
\text { Normal human pancreatic } \\
\text { ductal epithelial cell line } \\
\text { (HPDE) [77] } \\
\text { Human pancreatic cancer cell } \\
\text { lines (BxPC-3 and AsPC-1) } \\
\text { [78,79]. } \\
\text { Orthotopic PDAC tumor model } \\
\text { [78,79] }\end{array}$ & $\begin{array}{ll}\bullet & 1-60 \mu \mathrm{M}[77] \\
\bullet & 2.5-10 \mathrm{mM}[78,79] \\
\bullet & 10 \mathrm{mg} / \mathrm{kg}[78,79]\end{array}$ & $\begin{array}{l}\text { - Apoptosis activation } \\
\text { and cell cycle arrest, by } \\
\text { targeting of protein } \\
\text { phosphatase 2A } \\
\text { (PP2A), SRC, AKT and } \\
\text { p70S6k } \\
\text { ER stress }\end{array}$ & [77-79] \\
\hline Pimozide & Antipsychotic & $\begin{array}{l}\text { Psychological } \\
\text { disorders }\end{array}$ & + & & & $\begin{array}{l}\text { - Human pancreatic cancer cell } \\
\text { lines (BxPC-3 cells, Panc-1, } \\
\text { MiaPaCa-2, Capan-1 and } \\
\text { CFPAC-1) [80] } \\
\text { Human pancreatic cancer cell } \\
\text { line (MiaPaCa-2) [81] } \\
\text { PDAC primary cell cultures } \\
\text { [81] }\end{array}$ & - $\quad 0.1-10 \mathrm{mM}[80]$ & $\begin{array}{l}\text { - Inhibition of DRD2, ER } \\
\text { stress, cell cycle arrest, } \\
\text { activation of apoptosis } \\
\text { and activation of the } \\
\text { UPR }\end{array}$ & [80] \\
\hline
\end{tabular}


Table 2. Cont

\begin{tabular}{|c|c|c|c|c|c|c|c|c|c|}
\hline \multirow{2}{*}{ Drug } & \multirow{2}{*}{$\begin{array}{l}\text { Pharmacological } \\
\text { Class }\end{array}$} & \multirow{2}{*}{$\begin{array}{l}\text { Original } \\
\text { Indication }\end{array}$} & \multicolumn{3}{|c|}{ Evidence } & \multirow{2}{*}{ Biological Models } & \multirow{2}{*}{ Tested Concentrations } & \multirow{2}{*}{ Described Mechanisms } & \multirow{2}{*}{ References } \\
\hline & & & In Vitro & In Vivo & Clinical & & & & \\
\hline Trifluoperazine & Antipsychotic & $\begin{array}{l}\text { Psychological } \\
\text { disorders }\end{array}$ & + & + & & $\begin{array}{l}\text { - Human pancreatic cancer cell } \\
\text { line (MiaPaCa-2) } \\
\text { PDAC primary cell cultures } \\
\text { from xenografts (01008, HN01, } \\
\text { JIPC and LIPC) [81] }\end{array}$ & - $\quad 10-30 \mathrm{mM}$ & $\begin{array}{l}\text { Impairment of } \\
\text { mitochondrial and ER } \\
\text { homeostasis, induction } \\
\text { of apoptosis and } \\
\text { necroptosis and } \\
\text { activation of the UPR }\end{array}$ & [81] \\
\hline Disulfiram & $\begin{array}{l}\text { Drugs used in } \\
\text { addictive } \\
\text { disorders }\end{array}$ & $\begin{array}{l}\text { Treatment of } \\
\text { alcohol } \\
\text { dependence }\end{array}$ & + & + & & $\begin{array}{ll}\text { - } & \text { Human pancreatic cancer cell } \\
\text { lines (PDAC6 and Panc-1) [83] } \\
\text { Human pancreatic cancer cell } \\
\text { lines (Panc-1, PDAC-2, PDAC-2 } \\
\text { and PDAC-6) [84] } \\
\text { - Syngeneic PDAC mouse tumor } \\
\text { model (Panc02) [84] }\end{array}$ & $\begin{array}{ll}- & 0.25 \mathrm{mM}[83] \\
- & 0.2 \mathrm{and} 2.5 \mathrm{mM} \text { [84] } \\
& 50 \mathrm{mg} / \mathrm{kg} / \text { day, } 8 \text { days } \\
& {[84]}\end{array}$ & $\begin{array}{ll}\text { - Activation of } \\
\text { autophagy-dependent } \\
\text { apoptosis } \\
\text { ER stress by activation } \\
\text { of the IRE1a-XBP1 } \\
\text { pathway } \\
\text { Inhibition of the NF-kB } \\
\text { signaling pathway and } \\
\text { downregulate } \\
\text { stemness-related genes } \\
\text { (HER2, c-myc and } \\
\text { SOX9) }\end{array}$ & {$[83,84]$} \\
\hline Bazedoxifene & $\begin{array}{l}\text { Selective estrogen } \\
\text { receptor } \\
\text { modulator }\end{array}$ & $\begin{array}{l}\text { Postmenopausal } \\
\text { osteoporosis in } \\
\text { women at } \\
\text { increased risk of } \\
\text { fracture }\end{array}$ & + & + & & $\begin{array}{l}\text { - Human pancreatic cancer cell } \\
\text { lines (AsPC-1, PANC-1, } \\
\text { HPAF-II, BxPC-3, HPAC and } \\
\text { Capan-1) } \\
\text { - Human PDAC xenograft } \\
\text { mouse model }\end{array}$ & $\begin{array}{ll}\text { - } & 5-20 \mathrm{mM} \\
& 5 \mathrm{mg} / \mathrm{kg} / \text { day }\end{array}$ & $\begin{array}{l}\text { - Inhibition of STAT3 } \\
\text { activation mediated by } \\
\text { interleukin } 6 \text { (IL-6) and } \\
11 \text { (IL-11) }\end{array}$ & [85] \\
\hline Ibrutinib & $\begin{array}{l}\text { Antineoplastic } \\
\text { agents (protein } \\
\text { kinase inhibitors) }\end{array}$ & $\begin{array}{l}\text { Treatment of adult } \\
\text { patients with } \\
\text { relapsed or } \\
\text { refractory mantle } \\
\text { cell lymphoma } \\
\text { (MCL) }\end{array}$ & & + & & $\begin{array}{ll}\text { - } & \text { Transgenic PDAC mouse } \\
\text { model } \\
\text { - } \\
\text { Patient-derived xenograft } \\
\text { models }\end{array}$ & - $\quad 35 \mathrm{mg} / \mathrm{kg} /$ day & $\begin{array}{l}\text { - Mast cell-dependent } \\
\text { antifibrotic effect }\end{array}$ & {$[86-88]$} \\
\hline
\end{tabular}


Table 2. Cont.

\begin{tabular}{|c|c|c|c|c|c|c|c|c|c|}
\hline \multirow{2}{*}{ Drug } & \multirow{2}{*}{$\begin{array}{c}\text { Pharmacological } \\
\text { Class }\end{array}$} & \multirow{2}{*}{$\begin{array}{l}\text { Original } \\
\text { Indication }\end{array}$} & \multicolumn{3}{|c|}{ Evidence } & \multirow{2}{*}{ Biological Models } & \multirow{2}{*}{ Tested Concentrations } & \multirow{2}{*}{ Described Mechanisms } & \multirow{2}{*}{ References } \\
\hline & & & In Vitro & In Vivo & Clinical & & & & \\
\hline Losartan & $\begin{array}{l}\text { Angiotensin II } \\
\text { receptor } \\
\text { antagonist }\end{array}$ & Hypertension & & + & & $\begin{array}{l}\text { - Orthotopic PDAC mouse } \\
\text { model }\end{array}$ & - $\quad 10-60 \mathrm{mg} / \mathrm{kg}$ & $\begin{array}{l}\text { - Inhibition of collagen I } \\
\text { synthesis }\end{array}$ & [89] \\
\hline Pentoxifylline & Vasodilator & $\begin{array}{c}\text { Patients with } \\
\text { chronic occlusive } \\
\text { peripheral } \\
\text { vascular disorders } \\
\text { of the extremities }\end{array}$ & + & + & & $\begin{array}{ll}\text { - } & \text { Human pancreatic cancer cell } \\
\text { line (Capan-1) [90] } \\
\text { - } \\
\text { Human PDAC xenograft } \\
\text { mouse model [90] } \\
\text { - Human pancreatic cancer cell } \\
\text { line (BxPC-3 and Panc-1) [91] } \\
\text { Human monocytes isolated } \\
\text { from blood of healthy donors } \\
\text { [91] }\end{array}$ & $\begin{array}{ll}\text { - } & 50 \text { and } 100 \mathrm{mg} / \mathrm{kg} \text { per } \\
\text { - } & \text { day [90] } \\
& 0.4 \mathrm{mM} \text { [91] }\end{array}$ & 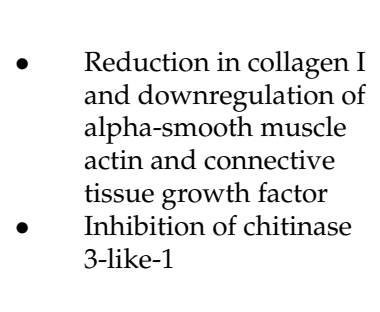 & {$[90,91]$} \\
\hline Pirfenidone & Antifibrotic & $\begin{array}{l}\text { Idiopathic } \\
\text { pulmonary } \\
\text { fibrosis }\end{array}$ & + & + & & $\begin{array}{ll}\text { - } & \text { Human PSCs from pancreatic } \\
\text { - } & \text { Oncer surgical specimens [92] } \\
\text { Orthotopic PDAC mouse } \\
\text { model [92] } \\
\text { Human PDAC xenograft } \\
\text { mouse model [92] } \\
\text { - } \quad \text { Human pancreatic cancer cell } \\
\text { lines (Panc-1, MiaPaca-2 and } \\
\text { BxPC-3) [93] } \\
\text { - Human skin fibroblasts } \\
\text { (ASF-4-1 cells) [93] } \\
\text { - Human pancreatic cancer cell } \\
\text { line (BxPC-3 and Panc-1) [91] } \\
\text { Human monocytes isolated } \\
\text { from blood of healthy donors } \\
\text { [91] }\end{array}$ & $\begin{array}{ll}\bullet & 0.1-1 \mathrm{mg} / \mathrm{mL} \text { [92] } \\
\bullet & 500 \mathrm{mg} / \mathrm{kg}[92] \\
\bullet & 0.1-0.5 \mathrm{mg} / \mathrm{mL}[93] \\
& 1 \mathrm{mM} \mathrm{[91]}\end{array}$ & $\begin{array}{ll}\text { - } & \text { Suppression of } \\
\text { desmoplasia through } \\
\text { regulation of PSCs } \\
\text { - } \quad \text { ell cycle arrest and } \\
\text { upregulation of p21 of } \\
\text { PDAC cells } \\
\text { Inhibition of } \\
\text { fibronectin }\end{array}$ & [91-93] \\
\hline
\end{tabular}

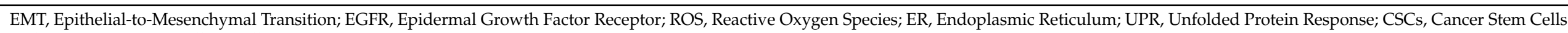
and PSCs, Pancreatic Stellate Cells. 


\subsection{Preclinical Studies}

\subsubsection{Carglumic Acid}

This orphan drug is commonly used to treat hyperammonemia, both in adult and pediatric patients. Surprisingly, a study demonstrated that carglumic acid is able to suppress $50 \%$ of cell viability in human and murine PDAC cell lines through induction of apoptosis [57]. Interestingly, the authors demonstrated that, while gemcitabine was more toxic to a human pancreatic ductal epithelial cell line than to PDAC cells, carglumic acid was more effective at inhibiting cancer cells than normal cells proliferation [57]. Additionally, carglumic acid showed promising in vivo effects by reducing $80 \%$ of the tumor growth in an orthotopic PDAC model [57].

\subsubsection{Warfarin}

In vitro and in vivo studies conducted by Kirane et al. (2015) pinpointed warfarin, an anticoagulant and vitamin $\mathrm{K}$ antagonist, as a very promising drug repurposing candidate in Axl-expressing pancreatic tumors [58]. This study showed that, by inhibiting Gas6 (a vitamin K-dependent ligand of the receptor tyrosine kinase Axl), low-dose warfarin impairs tumor cell growth, migration, invasiveness, angiogenesis and metastasis, while increasing the expression of apoptotic markers, without any complications in coagulation [58]. Interestingly, the same research group also demonstrated that low-dose warfarin could sensitize PDAC tumor cells to gemcitabine and nab-paclitaxel therapy in a KIC ( $p 48^{\mathrm{Cre}}$;

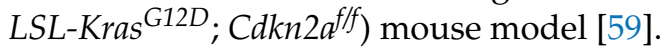

An immunomodulatory effect has also been described for low-dose warfarin in PDAC without any effect in coagulation [60]. Recently, Tormoen et al. observed that warfarin suppresses tyrosine-protein kinase Mer (MerTK) signaling, enhancing an adaptive immune response after Stereotactic Ablative Radiotherapy (SABR). MerTK is mainly expressed in macrophages and regulates the phagocytosis of apoptotic cancer cells, eliminating tumor antigens that could trigger an antitumor immune response and allowing irradiated tumor cells to evade immune control. Therefore, patients with PDAC undergoing SABR could benefit from warfarin as a stimulator of an antitumor adaptive immune response [60]. Regarding clinical evidence, a retrospective study found that a treatment with low-dose warfarin improved patient survival, independently of the type of chemotherapy received [61].

\subsubsection{Metformin}

A well-known antidiabetic drug, approved for type 2 diabetes mellitus (T2DM), is metformin, an oral antihyperglycemic drug [94]. As aforementioned, diabetes is a risk factor for PDAC, and it has been associated with a worse patient's outcome $[95,96]$. Interestingly, retrospective studies have shown that diabetic patients with pancreatic cancer (or other solid tumors) that were treated with metformin presented a cancer survival benefit when compared with patients treated with other antidiabetic drugs (for example, insulin or sulfonylureas [97]. These findings may be related to metformin's ability to influence various cellular pathways, including the activation of the LKB1/AMPK pathway, inhibition of cell division, promotion of apoptosis and autophagy and activation of the immune system [98]. Indeed, numerous studies have investigated the antitumor potential of metformin in a variety of cancers, alone or in combination with conventional chemotherapy. Besides its antidiabetic activity, metformin also exhibits anticancer effects, targeting multiple hallmarks of cancer both in vitro and in vivo. This anticancer effect has been explained by inhibition of mTOR, which prevents protein synthesis and cell growth, activation of the AMPK pathway, triggering activation of the tumor suppressors TSC2 and P53 and MAPK regulation, which controls cell proliferation, differentiation and survival, among others [99]. 
Candido et al. (2018) demonstrated that, although metformin could not inhibit cell growth by itself, a suboptimal dose of this drug was able to potentiate the effect of gemcitabine, 5-FU and cisplatin in different PDAC cell lines [62]. In fact, the association of metformin with conventional chemotherapy to treat PDAC is under evaluation in several clinical trials, as described in Section 3. Interestingly, the studies conducted by Chen et al. (2017) concluded that metformin also suppressed cancer initiation. This drug prevented the formation of precursor lesions and suppressed chronic pancreatitis-induced tumorigenesis in KC (LSL-KrasG12D; Pdx1-Cre) mice, partly by inhibiting cell proliferation and blocking STAT3 signaling [63]. Moreover, metformin improved the overall survival, reduced tumor volume and decreased abdominal invasions in KPC (LSL-Kras ${ }^{\mathrm{G} 12 \mathrm{D} /+}$; LSL-Trp53 ${ }^{\mathrm{R} 172 \mathrm{H} /+}$; Pdx1-Cre) mice, also playing a positive effect in pancreatic desmoplasia [63]. Furthermore, the activation of AMPK signaling and downregulation of p-mTOR were also observed in mice treated with metformin [63]. Additionally, the in vitro and in vivo results demonstrated that metformin could inhibit cell migration and invasion, as well as revert the expression of Epithelial-to-Mesenchymal Transition (EMT) markers, possibly through the suppression of TGF- $\beta 1 / \mathrm{Smad} 2 / 3$ signaling [64].

Evidence regarding whether pancreatic cancer patients might benefit from treatment with metformin is often contradictory. For instance, a retrospective study found that patients with T2DM and pancreatic cancer taking metformin had an increased overall survival when compared with patients in the same situation that were not taking metformin [100]. Contrary to these results, a randomized phase 2 trial in which 121 patients with advanced PDAC were randomly assigned to receive gemcitabine and erlotinib with either placebo $(n=61)$ or metformin in a conventional antidiabetic dosage $(n=60)$ showed no improvement in the clinical outcomes of patients belonging to the metformin group. It is important to note that this study included nondiabetic patients in both arms $(87 \%$ in the placebo group and $90 \%$ in the one receiving metformin), and patients with previous treatment with metformin or erlotinib within six months before the beginning of the study were not enrolled [101]. A meta-analysis performed by Dong et al. (2017) concluded that, while cohort studies favored the use of metformin in patients with pancreatic cancer, randomized controlled trials did not [102]. The discrepancies observed among studies might arise from several factors. Some observational studies overestimate the effects of metformin by using a time-fixed analysis, while others only include pancreatic cancer patients with diabetes who can benefit from metformin due to the concurrent disease. Besides, some studies do not differentiate pancreatic cancer stages, making it difficult to draw conclusions.

Interestingly, emerging evidence suggests a novel mechanism for the positive effect of metformin in PDAC patients. Several studies have demonstrated that microbiome plays a role in oncogenesis and can modulate cancer treatment response in several cancer types, including PDAC [103-109]. Moreover, several studies have reported that metformin modulates the gut microbiota in T2DM models, suggesting that its antidiabetic effect is also microbial-dependent [110-112]. Recently, Dong et al. (2019) showed that alterations in the duodenal microbiome composition, i.e., increased levels of Clostridium sensu stricto, were linked to PDAC development in KC mice undergoing a high fat and calories diet (HFCD) and that the treatment with metformin could decrease PDAC formation by reverting the Clostridium sensu stricto levels [113].

\subsubsection{Monensin}

This veterinary antibiotic is the product of natural fermentation by Streptomyces cinnamonensis and presents iontophoretic activity, forming a complex with monovalent cations and disrupting cell homeostasis, which leads to cell death [114]. Given its toxicity, monensin is not used in humans; however, it has been studied for drug repurposing in different types of malignancies, including pancreatic cancer [4]. Wang et al. (2018) demonstrated that monensin suppressed the cell proliferation and migration of gemcitabine resistant PDAC cells through apoptosis and cell cycle arrest at G1 and showed a synergistic effect with gemcitabine and erlotinib in suppressing cell growth and in inducing cell death [65]. 
Mechanistically, these authors demonstrated that monensin blocked the E2F/DP1, signal transducer and activator of transcription 1/2 (STAT1/2), nuclear factor- $\mathrm{kB}(\mathrm{NF}-\mathrm{Kb})$, activator protein 1 (AP-1) and ETS Like-1 protein Elk-1 (Elk-1)/Serum response factor (SRF)pathways and suppressed epidermal growth factor receptor (EGFR) expression [65]. In PDAC xenograft mouse models, monensin impaired tumor growth via the EGFR pathway [65].

\subsubsection{Nelfinavir and Nitroxoline}

The HIV protease inhibitor nelfinavir and the antibiotic nitroxoline have been studied for the treatment of pancreatic cancer as single agents or in combination with other drugs. Nelfinavir can sensitize pancreatic tumor cells to radiotherapy and has been tested for the treatment of different stages of pancreatic cancer [115-117]. Regarding nitroxoline, this drug has shown antitumor effects in distinct types of cancer, including the suppression of angiogenesis and inhibition of tumor cell migration and invasion [118].

Veschi et al. (2018) demonstrated that, while in monotherapy, nelfinavir and nitroxoline reduced cell viability and affected the cell cycle in several PDAC cell lines [66]. When combined with erlotinib, nelfinavir and nitroxoline, it displayed synergistic effects, strongly affecting cell viability through cell cycle arrest and apoptosis [66]. Interestingly, using a shotgun proteomic approach, the same authors demonstrated in another study that the anticancer effects of nitroxoline in PDAC cells were associated with increased reactive oxygen species (ROS) production and induction of the DNA damage response through downregulation of the $\mathrm{Na} / \mathrm{K}$-ATPase pump and $\beta$-catenin, as well as mitochondrial depolarization and deregulation of cytosolic iron homeostasis [67].

\subsubsection{Azithromycin, Doxycycline, Tigecycline and Pyrvinium}

Taking into consideration the Endosymbiotic Theory, which defends that mitochondria evolved from bacteria, it is no surprising that several classes of antibiotics, including tetracyclines, might have an off-target effect in the mitochondrial function $[69,119]$. In fact, the tetracycline and chloramphenicol families may inhibit mitochondrial and bacterial translation and affect some complexes of the mitochondrial respiratory chain [120]. Son et al. (2009) reported that doxycycline caused an inhibition of PDAC cell growth, an induction of apoptosis and cell cycle arrest [68]. Moreover, doxycycline reduced $80 \%$ of the tumor growth in a PDAC nude xenograft mouse model [68]. Interestingly, Lamb et al. (2015) studied several classes of antibiotics in pancreatic Cancer Stem Cells (CSCs) and showed that those drugs inhibited tumor-sphere formations in vitro and did not present toxicity in noncancer cells [69].

\subsubsection{Ritonavir}

Another promising antiviral drug that is described to have anticancer activity in both liquid and solids tumors is ritonavir, a FDA-approved drug for HIV treatment [121]. This drug impaired cancer cell growth and showed a synergistic effect with gemcitabine in different PDAC cell lines through alterations in apoptosis, cell cycle and cell motility and invasiveness [70]. The underlying mechanisms of the antitumor effect of ritonavir in vitro appears to be through suppression of the AKT pathway and sequestration of the E2F transcription factor 1 (E2F-1), preventing cell cycle progression to the S phase [70]. In contrast to these results, O'Donoghue et al. (2017) assessed the effect of ritonavir as a molecular inhibitor of cathepsin E (reported to be overexpressed in pancreatic cancer) on the tumor burden of PDAC mice. Although mouse PDAC tumors presented high levels of cathepsin E, ritonavir did not reduce the tumor burden in vivo [71]. However, no other effects of ritonavir in cancer cells were investigated in this study. Therefore, further studies need to be carried out to clarify the potential of this drug in PDAC treatment. 


\subsubsection{Itraconazole}

This broad-spectrum antifungal has been extensively studied as a drug-repurposing candidate in numerous types of cancers [4]. In fact, itraconazole was approved for treatment of nevoid basal-cell carcinoma syndrome (Gorlin syndrome) in 2017, due to its ability to block the Hedgehog signaling pathway by targeting Smoothened [18]. Similar to other malignancies, the Hedgehog signaling pathway is frequently altered in PDAC and was already associated with chemoresistance in this type of cancer [122-124]. Interestingly, itraconazole is also reported to inhibit P-glycoprotein, a key player in multidrug resistance in cancer $[125,126]$.

Cheng et al. (2018) reported that itraconazole could inhibit the cell viability, invasion and migration, as well as induce apoptosis, in several PDAC cell lines [72]. This antifungal drug also presented an anti-EMT effect, partly by suppressing TGF- $\beta$ /SMAD2/3 signaling, which seems essential for its anticancer activity in vitro, and inhibited tumor growth in a KPC mouse model [72]. Consistently, Jiang et al. (2018) also observed that itraconazole reduced the in vitro cell proliferation and tumor growth in a PDAC xenograft mouse model [73]. Moreover, itraconazole activated apoptosis through ROS production and depolarization of the mitochondrial membrane [73].

Regarding clinical evidence, a small retrospective study reported that the association of itraconazole with conventional chemotherapy (docetaxel, gemcitabine and carboplatin) had a positive effect in the overall survival and induced a partial response in some of the patients with refractory metastatic pancreatic cancer [127]. In addition, a case report study attributed to itraconazole the reduction of tumor size in a patient with unresectable pancreatic cancer, which allowed the patient to undergo curative surgery [128].

\subsubsection{Parbendazole}

This anthelmintic drug that is only approved for veterinary use, was also studied as a drug-repurposing candidate for the treatment of PDAC as a single agent or in combination therapy. Parbendazole decreased the cell viability and impaired the cell proliferation, clonogenicity and migration in different PDAC cell lines [74]. It also induced apoptosis, DNA damage, promoted G2/M cell cycle arrest and affected the tubulin distribution [74]. Moreover, when combined with gemcitabine, parbendazole decreased the cell viability in a dose-dependent manner, suggesting a chemosensitizing effect for this anthelmintic drug in PDAC cells [74].

\subsubsection{Verteporfin and Protoporphyrin IX}

Verteporfin is a photosensitizer agent that is used in photodynamic therapy for the treatment of aged-related macular degeneration by the generation of singlet oxygen, which induces cell death. Several studies have focused on the effect of verteporfin-based photodynamic therapy in the treatment of pancreatic cancer [129-131]. Regarding protoporphyrin IX, this drug is used in photodynamic therapy in glioma, due to its tumor-localizing properties [132]. However, it appears that these drugs by themselves, without light excitation, may also have antitumor effects $[75,133]$. Indeed, a study conducted by Acedo et al. (2019) demonstrated that verteporfin and protoporphyrin IX inhibited PDAC cell proliferation and induced apoptosis through the activation of tumor suppressor TAp73 and its proapoptotic targets PUMA, Bax and Bid, without any effect in a nontumoral cell line [75]. Moreover, these drugs induced the production of ROS species in vitro, most likely through the inhibition of thioredoxin reductase, a key redox regulator [75]. In another study, verteporfin partially reversed the effects of Platelet-Derived Growth Factor (PDGF)$\mathrm{BB}$ on cell proliferation, anoikis resistance and cell migration in vitro by suppressing the Hippo/YAP signaling pathway [76]. The Hippo tumor suppressor pathway consists of a serine kinase cascade that regulates cells survival and tissue growth, partly by blocking the Yes-associated protein (YAP) and Tafazzin (TAZ) [134]. YAP is responsible for the expression of several proto-oncogenes (e.g., CTGF, KRAS and Wnt/ $\beta$-catenin) and acts as a crucial transcription factor in promoting tumor formation and development $[134,135]$. 
Interestingly, YAP is also a downstream target of the KRAS signaling, and the increased expression of the YAP signaling network is correlated with poorer survival in PDAC patients [136].

\subsubsection{Olanzapine, Penfluridol, Pimozide and Trifluoperazine}

A lower incidence of some types of cancer was found in patients treated for schizophrenia [137]. Moreover, antipsychotics of the diphenylbutylpiperidine class, like penfluridol and pimozide, are known calcium channel antagonists and can bind to D2 dopamine receptor-binding sites, which is upregulated in many cancers and intimately related to stemness $[138,139]$.

Chien et al. (2015) demonstrated that penfluridol suppressed the cell proliferation of several PDAC cell lines without affecting the normal pancreatic epithelial cell line and, also, sensitized PDAC cells to gemcitabine treatment [77]. Moreover, penfluridol promoted apoptosis and cell cycle arrest by targeting the proteins phosphatase 2A (PP2A), SRC, AKT and p70S6k, which are key players in pancreatic tumorigenesis [77]. These results were in agreement with the ones observed by Ranjan et al. (2016), who showed that, in vitro, penfluridol induced apoptosis and blocked PDAC cell growth via autophagy and, in vivo, impaired tumor growth in different PDAC models [78]. In a subsequent study, the last authors proposed that the penfluridol-induced autophagy might also be linked to stress of the endoplasmic reticulum (ER) through the upregulation of ER stress markers, such as BIP, CHOP and IRE1a [79].

Pimozide is another antipsychotic candidate that has been investigated for the treatment of pancreatic cancer. Jandaghi et al. (2016) found that this drug reduced the growth and migration of PDAC cells through the inhibition of the dopamine receptor D2 (DRD2) protein. Moreover, a DRD2 blockage led to ER stress in pancreatic tumor cells, inducing cell cycle arrest, apoptosis and activation of the Unfolded Protein Response (UPR) [80]. Similar mechanisms were observed by Huang et al. (2019) for trifluoperazine, an antipsychotic drug from the phenothiazines family. PDAC cells treated with trifluoperazine showed a significant impairment in mitochondrial and ER homeostasis, prompting apoptosis and necroptosis. In addition, these authors verified that trifluoperazine-treated cells activated the ubiquitin-proteasome system (UPS) as a compensatory mechanism, and when PDAC-derived primary cells were cotreated with a proteosome inhibitor, the sensitivity to trifluoperazine increased up to 10 times [81].

Another antipsychotic that was also investigated as a drug-repurposing candidate in pancreatic cancer is olanzapine, which is considered an atypical antipsychotic drug due to its nonexisting or few adverse side effects. Besides its antipsychotic activity, olanzapine has an antiemetic effect, also being used in the prevention and treatment of chemotherapyinduced nausea and vomiting. In vitro studies demonstrated that olanzapine suppressed the expression of the antiapoptotic protein survivin in CSC lines established from PDAC cell lines and sensitized cancer cells to chemotherapeutics agents, such as 5-FU, gemcitabine and cisplatin, without causing any toxicity to normal cells such as fibroblasts [82].

\subsubsection{Disulfiram}

The anticancer activity of disulfiram (DSF), which is used in the treatment of chronic alcoholism, has been demonstrated in numerous in vitro and in vivo studies for different types of cancer. Moreover, its well-established chemo- and radio-sensitizing effect makes disulfiram a promising candidate for drug repurposing [140]. Due to its ability to chelate copper $(\mathrm{Cu})$, disulfiram forms DSF- $\mathrm{Cu}^{2+}$ complexes that block the $26 \mathrm{~S}$ proteasome activity and interfere with NF-kB, a transcription factor that controls cell proliferation and survival [141]. Disulfiram/Cu induced ER stress through activation of the IRE1a-XBP1 pathway in PDAC cell lines, activating autophagy-dependent apoptosis [83]. Moreover, another study reported that disulfiram/Cu targeted both PDAC stem and non-stem cells when combined with chemotherapy or chemoradiation [84]. In vivo, it was demonstrated that the combination treatment consisting of DSF/Cu + 5-FU + radiotherapy was the 
most effective in inhibiting tumor growth, when compared to 5-FU + radiotherapy or to FOLFIRINOX + radiotherapy [84]. In this study, disulfiram/Cu was also shown to inhibit the NF-kB pathway and to downregulate the stemness-related genes, such as HER2, c-myc and SOX9 [84].

\subsubsection{Bazedoxifene}

The selective estrogen modulator bazedoxifene is commonly used for osteoporosis prevention and treatment; however, due to its activity as a STAT3 inhibitor, increasing attention has been drawn to this molecule in the oncological field. In vitro and in vivo results demonstrated that bazedoxifene impaired the growth of pancreatic cancer cells with a persistent STAT3 activation. Additionally, in combination with paclitaxel or gemcitabine, bazedoxifene acted synergistically and inhibited the cell viability, as well as cell migration, in pancreatic cancer cells [85].

\subsubsection{Ibrutinib}

Massó-Vallés et al. (2015) reported that the drug ibrutinib, which is approved for the treatment of mast cells lymphoma as a suppressor of Bruton's tyrosine kinase, could impair PDAC cell growth and reduce tumor fibrosis in in vivo models. Moreover, ibrutinib improved the survival and response to gemcitabine in a transgenic mouse model of PDAC [86]. Importantly, these authors observed that mast cells play a major role in collagen deposition and that the antifibrotic effect of ibrutinib is mast cell-dependent [86]. Interestingly, other inhibitors of Bruton's tyrosine kinase have been also studied for the treatment of pancreatic cancer, highlighting its oncogenic role in this cancer $[87,88]$.

\subsubsection{Losartan}

Although losartan is commonly known as an angiotensin II receptor antagonist, to treat high blood pressure, it also displays antifibrotic properties. A study conducted by Diop-Frimpong et al. (2011) found that this drug inhibited collagen I synthesis in PDAC tumors and enhanced the transport and distribution of injected pegylated liposomal doxorubicin (Doxil) in orthotopic pancreatic tumors. Although losartan by itself did not impact tumor growth, a combination with Doxil decreased the tumor size by $50 \%$ in comparison with the Doxil treatment alone [89]. These results highlight the potential of losartan as an adjuvant drug with chemotherapy, which has been evaluated in several clinical trials (see Table 3). 


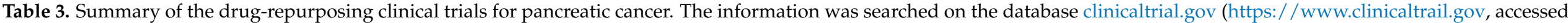
between 3 February and 28 February 2021).

\begin{tabular}{|c|c|c|c|c|c|c|}
\hline Class & Drug & Approved Indications & Trial Identifier & Phase & Title & Results \\
\hline \multirow{6}{*}{ 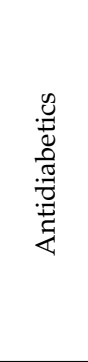 } & \multirow{5}{*}{ Metformin } & \multirow{6}{*}{ Type 2 diabetes mellitus } & NCT01210911 & II & Metformin Combined With Chemotherapy for Pancreatic Cancer (GEM) & $\begin{array}{l}\text { No patient outcome } \\
\text { improvement }\end{array}$ \\
\hline & & & NCT01666730 & II & Metformin Plus Modified FOLFOX 6 in Metastatic Pancreatic Cancer & Data not available \\
\hline & & & NCT01167738 & II & $\begin{array}{c}\text { Combination Chemotherapy With or Without Metformin Hydrochloride in Treating } \\
\text { Patients With Metastatic Pancreatic Cancer (PACT-17) }\end{array}$ & $\begin{array}{l}\text { Data not available. Study } \\
\text { closed }\end{array}$ \\
\hline & & & NCT02005419 & II & $\begin{array}{l}\text { Metformin Combined With Gemcitabine as Adjuvant Therapy for Pancreatic Cancer } \\
\text { After Curative Resection }\end{array}$ & Data not available \\
\hline & & & NCT01971034 & II & Treatment of Patients With Advanced Pancreatic Cancer After Gemcitabine Failure & $\begin{array}{l}\text { No patient outcome } \\
\text { improvement }\end{array}$ \\
\hline & Pioglitazone & & NCT01838317 & II & A Phase II Study of Pioglitazone for Patients With Cancer of the Pancreas & Data not available \\
\hline \multirow{11}{*}{ 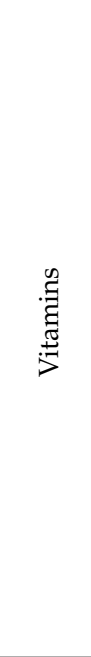 } & \multirow{6}{*}{ Ascorbic Acid } & \multirow{6}{*}{ Scurvy } & NCT01905150 & II & \multirow{6}{*}{$\begin{array}{c}\text { Ph } 2 \text { Trial of Vitamin C and G-FLIP (Low Doses Gemcitabine, 5FU, Leucovorin, } \\
\text { Irinotecan, Oxaliplatin) for Pancreatic Cancer } \\
\text { High Dose Vitamin C Combined With Metformin in the Treatment of Malignant Tumors } \\
\text { High Dose Vitamin C Intravenous Infusion in Patients With Resectable or Metastatic } \\
\text { Solid Tumor Malignancies } \\
\text { A Clinical Trial Evaluating the Effect of Pharmacological Ascorbate on Radiation } \\
\text { Therapy for Pancreatic Cancer Patients (XACT-PANC-2) } \\
\text { A Phase } 2 \text { Trial of High-dose Ascorbate for Pancreatic Cancer (PACMAN 2.1) } \\
\text { Trial of Ascorbic Acid (AA) + Nanoparticle Paclitaxel Protein Bound + Cisplatin + } \\
\text { Gemcitabine (AA NABPLAGEM) (AA NABPLAGEM) }\end{array}$} & Favorable toxicity profile \\
\hline & & & NCT04033107 & II & & Ongoing, recruiting \\
\hline & & & NCT03146962 & II & & Ongoing, recruiting \\
\hline & & & NCT03541486 & II & & Ongoing, not yet recruiting \\
\hline & & & NCT02905578 & II & & Ongoing, recruiting \\
\hline & & & NCT03410030 & $\mathrm{I} / \mathrm{II}$ & & Ongoing, recruiting \\
\hline & \multirow{5}{*}{ Paricalcitol } & \multirow{5}{*}{ Hyperparathyroidism } & NCT04524702 & II & \multirow{5}{*}{$\begin{array}{c}\text { Paricalcitol Trial } \\
\text { Paricalcitol and Hydroxychloroquine in Combination With Gemcitabine and } \\
\text { Nab-Paclitaxel for the Treatment of Advanced or Metastatic Pancreatic Cancer } \\
\text { Paricalcitol Plus Gemcitabine and Nab-paclitaxel in Metastatic Pancreatic Cancer } \\
\text { Paricalcitol Addition to Chemotherapy in Patients With Previously Untreated Metastatic } \\
\text { Pancreatic Ductal Adenocarcinoma (PINBALL) } \\
\text { Pre-operative Treatment for Patients With Untreated Pancreatic Cancer } \\
\text { Paclitaxel Protein Bound Plus Cisplatin Plus Gemcitabine and Paricalcitol for Pancreatic } \\
\text { Adenocarcinoma (NABPLAGEMD) (NABPLAGEMD) }\end{array}$} & Ongoing, recruiting \\
\hline & & & NCT03520790 & $\mathrm{I} / \mathrm{II}$ & & Ongoing \\
\hline & & & NCT04054362 & II & & Ongoing, recruiting \\
\hline & & & NCT03138720 & II & & Ongoing, recruiting \\
\hline & & & NCT03415854 & II & & Ongoing \\
\hline \multirow{5}{*}{ 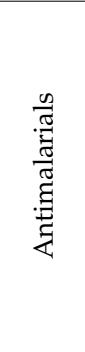 } & \multirow{4}{*}{ Hydroxychloroquine } & \multirow{4}{*}{$\begin{array}{l}\text { Malaria Lupus } \\
\text { erythematosus Rheumatoid } \\
\text { arthritis }\end{array}$} & NCT04524702 & II & \multirow{4}{*}{$\begin{array}{c}\text { Paricalcitol and Hydroxychloroquine in Combination With Gemcitabine and } \\
\text { Nab-Paclitaxel for the Treatment of Advanced or Metastatic Pancreatic Cancer } \\
\text { Phase II Study of Paclitaxel Protein Bound + Gemcitabine + Cisplatin + } \\
\text { Hydrochloroquine as Treatment in Untreated Pancreas Cancer } \\
\text { A Phase I/II/Pharmacodynamic Study of Hydroxychloroquine in Combination With } \\
\text { Gemcitabine/Abraxane to Inhibit Autophagy in Pancreatic Cancer } \\
\text { Short Course Radiation Therapy With Proton or Photon Beam Capecitabine and } \\
\text { Hydroxychloroquine for Resectable Pancreatic Cancer }\end{array}$} & Ongoing, recruiting \\
\hline & & & NCT04669197 & II & & Ongoing, recruiting \\
\hline & & & NCT01506973 & $\mathrm{I} / \mathrm{II}$ & & Ongoing \\
\hline & & & NCT01494155 & II & & Ongoing \\
\hline & Chloroquine & $\begin{array}{l}\text { Malaria Extraintestinal } \\
\text { amebiasis }\end{array}$ & NCT01777477 & I & Adjuvant Effect of Chloroquine on Gemcitabine & Combination well tolerated \\
\hline
\end{tabular}


Table 3. Cont.

\begin{tabular}{|c|c|c|c|c|c|c|}
\hline Class & Drug & Approved Indications & Trial Identifier & Phase & Title & Results \\
\hline \multirow{6}{*}{ 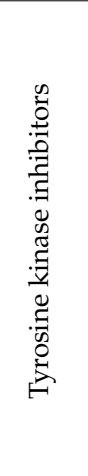 } & \multirow{3}{*}{ Ruxolitinib } & \multirow{3}{*}{$\begin{array}{l}\text { Myelofibrosis Polycythemia } \\
\text { vera }\end{array}$} & NCT01423604 & II & Study of Ruxolitinib in Pancreatic Cancer Patients (RECAP) & $\begin{array}{c}\text { Improvement in overall } \\
\text { survival }\end{array}$ \\
\hline & & & NCT02117479 & III & Study of Ruxolitinib in Pancreatic Cancer Patients (Janus 1) & $\begin{array}{l}\text { Well tolerated. No survival } \\
\text { improvement }\end{array}$ \\
\hline & & & NCT02119663 & III & A Study of Ruxolitinib in Pancreatic Cancer Patients & $\begin{array}{l}\text { Well tolerated. No survival } \\
\text { improvement }\end{array}$ \\
\hline & \multirow{2}{*}{ Masitinib } & \multirow{2}{*}{ Mast-cell tumour in dogs } & NCT00789633 & III & $\begin{array}{c}\text { Masitinib in Combination With Gemcitabine for Treatment of Patients With } \\
\text { Advanced/Metastatic Pancreatic Cancer }\end{array}$ & $\begin{array}{l}\text { Improvement in overall } \\
\text { survival }\end{array}$ \\
\hline & & & NCT03766295 & III & Masitinib Plus Gemcitabine in Pancreatic Cancer & $\begin{array}{l}\text { Improvement in survival } \\
\text { and pain reduction }\end{array}$ \\
\hline & Sorafenib & $\begin{array}{l}\text { Hepatocellular carcinoma } \\
\text { Renal cell carcinoma Thyroid } \\
\text { carcinoma }\end{array}$ & NCT00541021 & III & $\begin{array}{l}\text { Gemcitabine With or Without Sorafenib in Treating Patients With Locally Advanced or } \\
\text { Metastatic Pancreatic Cancer }\end{array}$ & $\begin{array}{l}\text { No improvement in free } \\
\text { survival }\end{array}$ \\
\hline \multirow{4}{*}{ 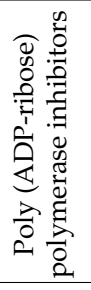 } & \multirow[b]{2}{*}{ Niraparib } & \multirow{2}{*}{$\begin{array}{l}\text { Fallopian tube cancerOvarian } \\
\text { epithelial cancer } \\
\text { Primary peritoneal cancer }\end{array}$} & NCT03601923 & II & \multirow{2}{*}{$\begin{array}{c}\text { Niraparib in Patients With Pancreatic Cancer } \\
\text { Niraparib in Metastatic Pancreatic Cancer After Previous Chemotherapy (NIRA-PANC): } \\
\text { a Phase } 2 \text { Trial (NIRA-PANC) }\end{array}$} & Ongoing, recruiting \\
\hline & & & NCT03553004 & II & & Ongoing, recruiting \\
\hline & \multirow{2}{*}{ Rucaparib } & \multirow{2}{*}{$\begin{array}{l}\text { Ovarian cancer Prostate } \\
\text { cancer }\end{array}$} & NCT02042378 & II & $\begin{array}{l}\text { A Study of Rucaparib in Patients With Pancreatic Cancer and a Known Deleterious } \\
\text { breast cancer gene (BRCA) Mutation }\end{array}$ & Safe and clinically relevant \\
\hline & & & NCT03140670 & II & $\begin{array}{c}\text { Maintenance Rucaparib in BRCA1, BRCA2 or PALB2 Mutated Pancreatic Cancer That } \\
\text { Has Not Progressed on Platinum-based Therapy }\end{array}$ & Ongoing \\
\hline \multirow{5}{*}{ 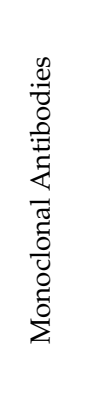 } & \multirow{4}{*}{ Bevacizumab } & \multirow{4}{*}{$\begin{array}{c}\text { Colorectal cancerNon-small } \\
\text { cell lung cancer } \\
\text { Glioblastoma } \\
\text { Cervical cancer } \\
\text { Renal cell carcinoma }\end{array}$} & NCT01214720 & III & $\begin{array}{c}\text { A Study of Avastin (Bevacizumab) Added to a Chemotherapeutic Regimen in Patients } \\
\text { With Metastatic Pancreatic Cancer }\end{array}$ & $\begin{array}{c}\text { Improvement in } \\
\text { progression-free survival } \\
\text { No improvement in overall } \\
\text { survival }\end{array}$ \\
\hline & & & NCT00894 & III & $\begin{array}{c}\text { Gemcitabine With or Without Bevacizumab in Treating Patients With Locally Advanced } \\
\text { or Metastatic Pancreatic Cancer }\end{array}$ & $\begin{array}{l}\text { No improvement in overall } \\
\text { survival }\end{array}$ \\
\hline & & & NCT03351296 & II & Two Chemotherapy Regimens Plus or Minus Bevacizumab (BETTER 2) & Ongoing, recruiting \\
\hline & & & NCT03193190 & $\mathrm{I} / \mathrm{II}$ & $\begin{array}{l}\text { A Study of Multiple Immunotherapy-Based Treatment Combinations in Participants } \\
\text { With Metastatic Pancreatic Ductal Adenocarcinoma (Morpheus-Pancreatic Cancer) }\end{array}$ & Ongoing, recruiting \\
\hline & Cetuximab & $\begin{array}{l}\text { Head and neck cancer } \\
\text { Colorectal cancer }\end{array}$ & NCT00075686 & III & $\begin{array}{l}\text { S0205 Gemcitabine w/or w/o Cetuximab as First-Line Therapy in Locally Advanced } \\
\text { Pancreas Cancer }\end{array}$ & $\begin{array}{l}\text { No improvement in median } \\
\text { survival time or } \\
\text { progression-free survival }\end{array}$ \\
\hline
\end{tabular}


Table 3. Cont

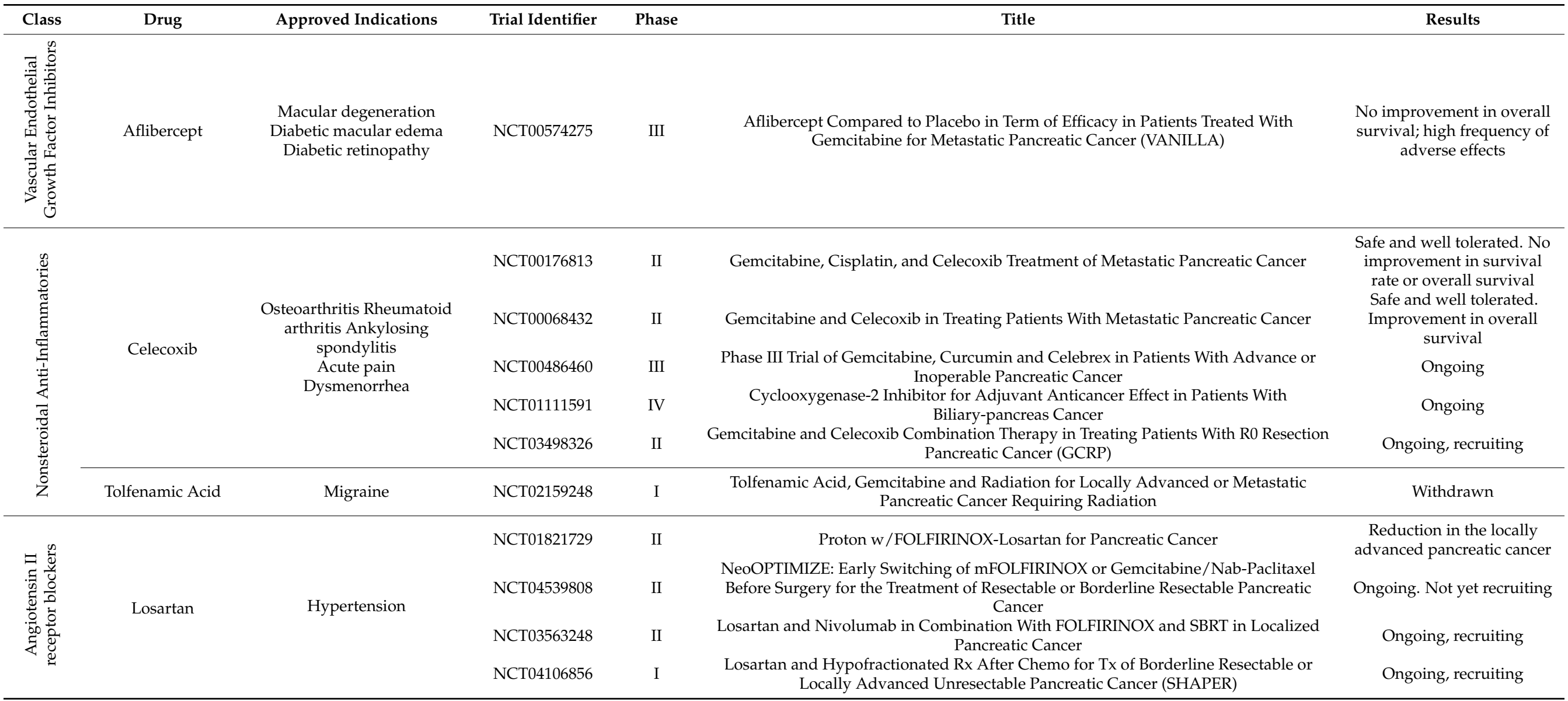




\subsubsection{Pentoxifylline and Pirfenidone}

Kim et al. (2017) demonstrated that the vasodilator pentoxifylline increased the efficacy of gemcitabine in vivo by improving the drug delivery, which led to a 50\% decrease in tumor growth. Reductions in the levels of collagen I and in the number of activated fibroblasts were observed but not in vessel density, suggesting that pentoxifylline also has an antifibrotic effect [90].

The antifibrotic activity of pirfenidone, which is used to treat idiopathic pulmonary fibrosis, has also been studied in pancreatic cancer. Kozono et al. (2013) reported that pirfenidone inhibited the in vitro proliferation, invasiveness, and migration of PSCs, which are intricately connected to desmoplasia in PDAC and contribute to the malignancy and chemoresistance of cancer cells. Pirfenidone also reduced the expression of genes associated with tumor-stromal interactions in human PSCs from PDAC patient samples and in vivo, it inhibited the growth of PSCs and presented synergistic effects with gemcitabine [92]. Another work also reported that pirfenidone may directly target PDAC cells, in addition to fibroblasts and stromal cells [93].

Xavier et al. (2021) also demonstrated that the treatment of PDAC tumor cells with pentoxifylline and pirfenidone could partially reverse the chemoresistance to gemcitabine. These drugs are inhibitors of chitinase 3-like-1 and fibronectin, respectively, two proteins that the authors found to be in the cargo of extracellular vesicles shed by human macrophages and are responsible of gemcitabine resistance in vitro [91].

\section{Repurposed Drugs for Pancreatic Cancer in Clinical Trials}

Given all the advantages of drug repurposing, there are several drugs previous approved for other diseases that are currently under different phases of clinical trials for the treatment of pancreatic cancer. Based on the database "clinicaltrials.gov", this review summarizes the most relevant classes of drugs under investigation in clinical trials for the treatment of pancreatic cancer (Table 3).

\subsection{Antidiabetics}

In general, patients with diabetes are more prone to several types of cancer that may be related with a chronic increase in glycemia, partially contributing to tumor development [3]. In fact, around $80 \%$ of pancreatic cancer patients have concomitant diabetes, which is regarded as a poor prognostic factor. On the other hand, damaged pancreatic tissue promotes a replacement of islet and beta cells by malignancy, leading to diabetes. Consequently, diabetes is both a potential cause and effect of this disease [98]. Thus, the possibility of repurposing metformin as an adjuvant drug in chemotherapy for pancreatic cancer treatment has emerged. Indeed, several phase II clinical trials, in which metformin was added to the traditional chemotherapy regimens compared with chemotherapy given alone, are being performed on pancreatic cancer (NCT01210911, NCT01666730, NCT01167738, NCT02005419 and NCT01971034) [142-146]. So far, only two of these studies have had their results published (NCT01210911 and NCT01971034). The study NCT01210911 showed that adding metformin in a conventional antidiabetic dosage to gemcitabine and erlotinib treatments in patients with advanced or metastatic pancreatic cancer did not improve the outcomes in patients. Although not encouraging, these results suggested that, for future trials, the focus should be on patients with hyperinsulinemia or patients with tumorsexpressing markers of sensitivity to energetic stress, such as the loss of function of the AMP kinase, a key regulator of cellular energy homoeostasis [101]. Unfortunately, regarding the clinical trial NCT01971034, the authors concluded that the addition of metformin to paclitaxel in patients with locally advanced or metastatic pancreatic cancer whose disease progressed when treated with gemcitabine did not improve the overall survival or progression-free survival [147].

Another antidiabetic drug studied with promising potential in the treatment of pancreatic cancer is pioglitazone, a Proliferator-activated receptor- $\gamma$ (PPAR- $\gamma$ ) ligand, approved by the FDA for type 2 diabetes [148]. PPAR- $\gamma$ is a nuclear receptor that functions as a 
transcription factor in different tissues. PPAR- $\gamma$ ligands, such as pioglitazone, are being studied for their ability to inhibit numerous cancer cell processes [149]. In a recently closed phase II clinical trial (NCT01838317), pioglitazone was added to the standard chemotherapy, aiming to evaluate its effects on glucose and insulin metabolism, tumor size, weight gain and the general quality of life of pancreatic cancer patients. The results of this study are not published yet [150].

\subsection{Vitamins}

Ascorbic acid is a water-soluble vitamin, commonly named vitamin C, which appears abundantly in fresh fruit, especially blackcurrants, citrus fruit and strawberries, and in most fresh vegetables [151]. Many health benefits have been associated with this vitamin, such as antioxidant, antiatherogenic, anticarcinogenic and immunomodulatory [152]. Curiously, pharmacological concentrations of ascorbate can generate hydrogen peroxide, inducing oxidative damage, with this cytotoxicity apparently being selective to different types of cells (with a higher toxicity to cancer cells than to normal cells). Thus, several authors became interested in the clinical repurposing of intravenous high doses of ascorbate in pancreatic cancer. The doses reported in different studies vary. However, several trials used around 25 to $100 \mathrm{~g}$ per infusion [153].

In a phase II clinical trial of the study NCT01905150, the authors compared the administration of G-FLIP (low doses of gemcitabine, fluorouracil, leucovorin, irinotecan and oxaliplatin) and G-FLIP-DM (low doses of gemcitabine, fluorouracil, leucovorin, irinotecan, oxaliplatin, docetaxel and mitomycin C) alone versus their combinations with a high dose of ascorbic acid in patients with advanced pancreatic cancer [154]. The results of this study demonstrated that the conventional therapy combined with high doses of ascorbic acid caused an overall survival at 11 months of $75 \%$ and a disease control rate (including complete response, partial response and stable disease) of 73\%. Regarding the toxicity profile, the hematologic adverse events registered were mostly mild (Grade 1 and 2 ), some Grade 3 and no Grade 4 . The nonhematologic adverse events were also mostly Grade 1 or 2 , except $6 \%$ of Grade 3 with diarrhea and thromboembolism. Furthermore, no Grade 3 or 4 nausea, vomiting or neuropathy were registered. Therefore, the combination was considered well-tolerated by the patients and should be further explored, especially in elderly patients and patients who are not candidates for high doses of conventional therapy [155]. Currently, there are several ongoing clinical trials that aim to explore the potential use of this vitamin in pancreatic cancer using different approaches: high doses of vitamin C alone (NCT03146962 and NCT02905578), in combination with metformin (NCT04033107), in combination with radiation therapy (NCT03541486) or in combination with standard chemotherapy regimens (NCT03410030). So far, no results from these trials have been published [156-160].

Paricalcitol is a synthetic analog of calcitriol, the metabolically active form of vitamin D, approved by the FDA for the prevention and treatment of secondary hyperparathyroidism associated with chronic kidney disease [161]. Interestingly, studies have shown an association between vitamin $\mathrm{D}$ and cancer due to $1 \alpha, 25(\mathrm{OH}) 2 \mathrm{D}$, the biologically active form of vitamin $\mathrm{D}$, which functions as a hormone with several activities, including the inhibition of cellular proliferation, induction of differentiation and apoptosis. However, the systemic administration of $1 \alpha, 25(\mathrm{OH}) 2 \mathrm{D} 3$ leads to lethal hypercalcemia, not allowing its use as a possible cancer treatment. To overcome this issue, synthetic analogs with less calcemic effects and more potent growth inhibitors have been developed, including Paricalcitol [162]. This vitamin D analog has been included in several phase II clinical trials (NCT04617067, NCT04524702, NCT03520790, NCT04054362, NCT03138720 and NCT03415854) to study its effect in combination with the usual chemotherapy regimens in patients with pancreatic cancer [163-168]. These studies are still ongoing, and thus, no results are so far available. 


\subsection{Hydroxychloroquine and Chloroquine}

Hydroxychloroquine and chloroquine are 4-aminoquinoline compounds. While hydroxychloroquine is approved by the FDA for the treatment of malaria, lupus erythematosus and rheumatoid arthritis, chloroquine is approved for the treatment of malaria and extraintestinal amebiasis $[169,170]$. These compounds may have a role in cancer treatment due to their ability to inhibit autophagy, which enhances the efficacy of several chemotherapeutic and targeted therapies [171]. Thus, repurposing these drugs may be extremely promising for autophagy-dependent malignant tumors, including pancreatic cancer, known to be highly dependent on this mechanism for survival $[3,172,173]$. Therefore, there are several ongoing clinical trials aiming to evaluate the combination of hydroxychloroquine with the standard chemotherapy regimens and/or radiation (NCT04524702, NCT04669197, NCT01506973 and NCT01494155) [164,174-176]. Chloroquine has also been tested in a phase I trial (NCT01777477) to evaluate its safety and preliminary efficacy when combined with gemcitabine [177]. The results have shown that this combination was well-tolerated in patients with metastatic or unresectable pancreatic cancer [178] and, therefore, should be further explored.

\subsection{Tyrosine Kinase Inhibitors (TKIs)}

Currently, there are two TKIs approved for the treatment of pancreatic cancer-namely, erlotinib and sunitinib [179]. These drugs were previously approved by FDA for other types of cancers, such as metastatic non-small cell lung cancer and gastrointestinal or advanced renal cell carcinoma, respectively $[180,181]$, making them the first successful examples of TKIs approved for pancreatic cancer.

Nowadays, other similar molecules are under clinical trials, such as ruxolitinib, which is a selective inhibitor of the Janus kinase 1 (JAK1) and Janus kinase 2 (JAK2) enzymes, approved by the FDA for the treatment of post-essential thrombocythemia myelofibrosis, post-polycythemia vera myelofibrosis, high- and intermediate-risk myelofibrosis and refractory polycythemia vera [182]. Studies have shown that the JAK/signal transducer is at least partly involved in the systemic inflammatory response showed by patients with pancreatic cancer. In a phase II clinical trial (NCT01423604) with metastatic pancreatic cancer patients resistant to gemcitabine, those receiving ruxolitinib plus capecitabine had a survival improvement, especially the patients showing systemic inflammation, when compared with the ones receiving the placebo plus capecitabin $[183,184]$. Due to this promising data, two clinical trials in phase III were conducted (NCT02117479 and NCT02119663) to evaluate the effects of ruxolitinib in combination with capecitabine in patients with advanced/metastatic pancreatic cancer after disease progression or who presented an intolerance to the first-line therapy. Unfortunately, both trials were terminated earlier due to an interim futility analysis (it appears that the experimental arm was unlikely to show better results than the control arm if the trial was continued to the final analysis). Although well-tolerated, the efficacy of ruxolitinib in improving patients' survival and clinical outcomes has not yet been proven [185-187].

Another example of a TKI is masitinib, which is approved by the European Committee for Medicinal Products for Veterinary Use for the treatment of mast-cell tumors with a mutation in the receptor protein c-kit in dogs [188]. This drug was evaluated in a phase III clinical trial (NCT00789633) in combination with gemcitabine in pancreatic cancer patients, revealing an improvement in the overall survival when compared with gemcitabine alone $[189,190]$. Later, similar studies were conducted in another phase III clinical trial (NCT03766295), showing that masitinib was able to improve the survival and reduce the pain in patients with unresectable locally advanced pancreatic cancer [191,192].

Sorafenib is another potent TKI already approved by the FDA to treat unresectable hepatocellular carcinoma, advanced renal cell carcinoma and thyroid carcinoma [193]. This drug interferes with Raf-1, a member of the RAF/MEK/ERK signaling pathway, which plays a critical role in pancreatic cancer cell proliferation [194]. Unfortunately, in a phase III trial (NCT00541021) with locally advanced or metastatic pancreatic cancer 
patients, the administration of gemcitabine with sorafenib failed to demonstrate a superior progression-free survival in comparison with gemcitabine alone [195,196].

\subsection{Poly (ADP) Ribose Polymerase (PARP) Inhibitors}

Poly (ADP) ribose polymerases (PARPs) are a large family of nuclear proteins with an important role in DNA repair pathways, especially in the repair of single-strand breaks $[197,198]$. PARP inhibitors can prevent DNA repair and allow the accumulation of single-strand breaks. The efficacy of PARP inhibitors is advantageous in the treatment of malignancies that present mutations in homologous recombination repair enzymes, such as breast cancer gene (BRCA), BRCA1 and BRCA2 (being unable to repair these breaks) [199].

The PPAR inhibitor olaparib has previously been approved by the FDA to treat ovarian and breast cancers [200]. Recently, in 2019, the FDA approved olaparib for the treatment of BRCA-mutated metastatic pancreatic cancer. This decision was based on the results from a clinical trial (NCT02184195) that showed a longer progression-free survival when olaparib was added to patient's treatment regimen [201,202].

Niraparib is another PARP inhibitor that was initially approved for the treatment of fallopian tube cancer, ovarian epithelial cancer and primary peritoneal cancer [203]. Currently, this drug is being investigated in phase II clinical trials (NCT03601923 and NCT03553004) in unresectable or metastatic pancreatic cancer patients possessing germline or somatic mutations in genes involved in DNA repair [204,205].

Another PARP inhibitor that can potentially be repurposed for pancreatic cancer treatment is rucaparib, a drug previously approved by the FDA for the treatment of ovarian and prostate cancer [206]. In a clinical trial (NCT02042378), rucaparib proved to be safe and clinically relevant in advanced pancreatic cancer patients with BRCA1/2 mutations $[207,208]$. In another ongoing phase II clinical trial (NCT03140670), rucaparib is being tested on pancreatic cancer patients with a locally advanced or metastatic disease possessing a germline or somatic deletion in BRCA1/2 or PALB2 mutations [209].

\subsection{Monoclonal Antibodies ( $m A b)$}

Several clinical trials at different stages are being conducted with monoclonal antibodies $(\mathrm{mAb})$ for the treatment of pancreatic cancer. The most relevant monoclonal antibodies in this context are bevacizumab and cetuximab, since they have already reached phase III clinical trials. Bevacizumab is a vascular endothelial growth factor (VEGF) inhibitor approved by the FDA for the treatment of metastatic colorectal cancer, non-squamous non-small cell lung cancer, glioblastoma, cervical cancer and metastatic renal cell carcinoma [210]. In a phase III clinical trial (NCT01214720), this mAb was tested in combination with gemcitabine and erlotinib in patients with metastatic pancreatic cancer. The results demonstrated that, when bevacizumab was added to gemcitabine and erlotinib treatments, progression-free survival was significantly longer; however, no significant improvement in the overall survival was verified [211,212]. Bevacizumab was also studied in combination with gemcitabine in a phase III trial (NCT00088894) in advanced pancreatic cancer patients. Unfortunately, these authors concluded that bevacizumab did not improved patient survival $[213,214]$. In spite of the inconsistent data so far, this $\mathrm{mAb}$ is still under investigation in at least two phase II clinical trials (NCT03351296 and NCT03193190) [215,216].

Cetuximab is an EGFR antagonist already approved to treat head and neck cancer, as well as colorectal cancer [217]. Several clinical trials have also been conducted in pancreatic cancer. In a phase III trial (NCT00075686), no significant differences in the median survival time and progression-free survival were observed between the combination gemcitabine/cetuximab and gemcitabine alone [218,219].

\subsection{Other Relevant Examples}

Aflibercept is a VEGF inhibitor currently used to treat eye pathologies like neovascular age-related macular degeneration, diabetic macular edema and diabetic retinopathy [220]. A phase III clinical trial (NCT00574275) was conducted to evaluate the effectiveness of 
aflibercept in increasing the overall survival of metastatic pancreatic cancer patients treated with gemcitabine [221]. Unfortunately, the addition of aflibercept did not bring a survival advantage when comparing with the standard treatment, making the frequency of the adverse events even higher [222].

Celecoxib is a nonsteroidal anti-inflammatory drug approved by the FDA for the treatment of osteoarthritis, rheumatoid arthritis, ankylosing spondylitis, acute pain and primary dysmenorrhea. Celecoxib is a selective Cyclooxygenase-2 (COX-2 inhibitor [223], which is an enzyme known to be upregulated in various gastrointestinal tumors, including pancreatic adenocarcinoma [224]. In phase II clinical trials (NCT00176813 and NCT00068432), celecoxib was combined with standard chemotherapy drugs to determine the overall survival and clinical outcomes of pancreatic metastatic cancer patients $[225,226]$. Both studies concluded that the administration of celecoxib in combination with gemcitabine is safe and well-tolerated. However, their efficacy was not consistent between the two trials. While, in the clinical trial NCT00068432, the authors concluded that the combination of gemcitabine and celecoxib was beneficial compared to gemcitabine individually, in the NCT00176813 trial, the combination of celecoxib with gemcitabine and cisplatin did not reveal a significant impact on the survival rate and overall survival of the patients $[227,228]$. In a phase III clinical trial (NCT00486460), celecoxib in combination with gemcitabine and curcumin are being evaluated in advanced or inoperable pancreatic cancer patients [229]. The potential adjuvant anticancer effect of celecoxib is also being evaluated in another clinical trial (NCT01111591) [230]. An ongoing phase II study (NCT03498326) is also evaluating the synergistic effect of celecoxib in combination with gemcitabine for the treatment of resection pancreatic cancer patients [231].

Tolfenamic acid is another nonsteroidal anti-inflammatory drug used to treat migraines that has demonstrated antitumor activity in preclinical pancreatic models, especially when in combination with gemcitabine and radiation therapy. A phase I clinical trial (NCT02159248) was planned, aiming to determine the maximum tolerated dose, safety and the antitumor activity of locally advanced or metastatic pancreatic patients treated with gemcitabine and radiation in combination with tolfenamic acid. Unfortunately, this study was closed prior to enrolling participants, and therefore, no results are presented [232].

Losartan is an angiotensin II receptor blocker approved by the FDA and indicated for the treatment of hypertension and reduction of the risk of stroke in patients with hypertension and left ventricular hypertrophy and diabetic nephropathy [233] (see Section 3.1.15). In a phase II clinical trial (NCT01821729), the authors showed that losartan provides a downstaging of locally advanced pancreatic cancer when combined with a FOLFIRINOX treatment $[234,235]$. Currently, several ongoing clinical trials at different phases are being conducted to further study the benefit of using losartan in the treatment of pancreatic cancer (NCT04539808 in phase II, NCT03563248 in phase II and NCT04106856 in phase I) [236-238].

\section{Conclusions}

Drug repurposing is efficient, cost-effective and riskless and no longer a result of serendipity but, rather, a rational process benefiting from systematic approaches and modern technologies (omics, bioinformatics, machine learning, etc.). It is undeniable that this is a resourceful strategy to broaden the therapeutic options in pancreatic cancer and provide a faster response to the main challenges of this disease, particularly to drug toxicity, chemoresistance and desmoplasia. As highlighted in this review, there are numerous drug-repurposing candidates that could potentially be used in PDAC treatments, some of which are already undergoing clinical trials, as summarized in Figure 2. Although additional studies are required to ensure the safety and effectiveness of many of these drugrepurposing candidates, this possibility offers a new hope for pancreatic cancer treatment. 


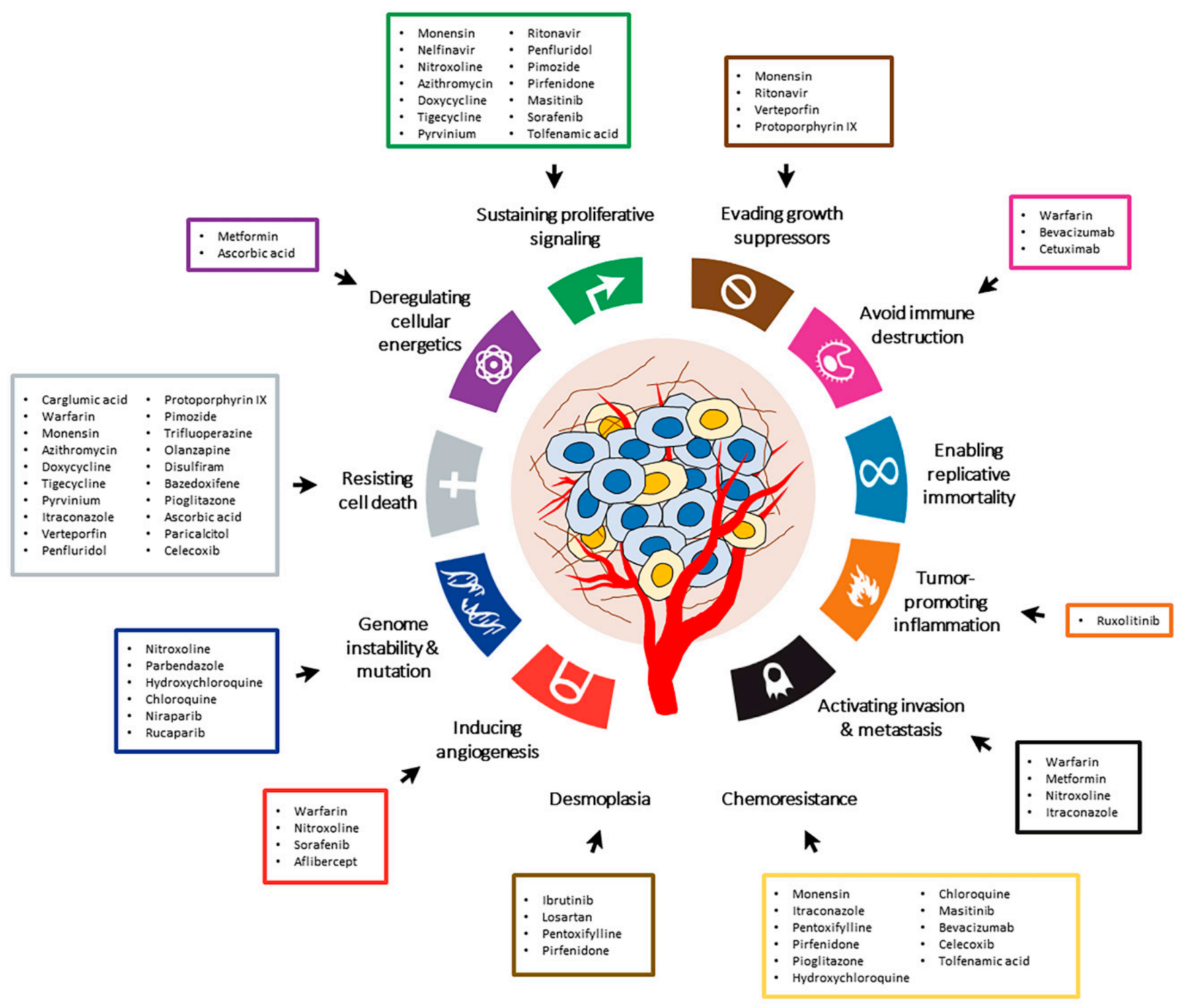

Fibrosis PDAC cells (O) TME cells

Figure 2. The hallmarks of cancer and other pathological characteristics of pancreatic ductal adenocarcinoma (PDAC) that may be targeted by drug repurposing candidates. These drugs have been investigated in preclinical studies or clinical trials for the treatment of PDAC. Adapted from Hanahan and Douglas et al. 2011.

Author Contributions: Conceptualization: M.H.V. and C.P.R.X.; writing-original draft preparation: R.R., B.P. and C.P.R.X.; writing-review and editing, R.R., B.P., L.L.S., C.P.R.X. and M.H.V. and supervision: M.H.V. and C.P.R.X. All authors have read and agreed to the published version of the manuscript.

Funding: This research received no external funding.

Acknowledgments: Cristina P. R. Xavier was supported by the Fundação para a Ciência e Tecnologia (FCT) and Fundo Social Europeu (FSE), Portugal, through the post-doc grant SFRH/BPD/122871/2016. This research group is supported by FEDER-Fundo Europeu de Desenvolvimento Regional through COMPETE 2020 and by FCT-Foundation for Science and Technology in the framework of project POCI-01-0145-FEDER-030457 and project POCI-01-0145-FEDER-016390:CANCEL STEM. 
Conflicts of Interest: The authors declare no conflict of interest. M.H.V. is member of the research team of a project financed by Celgene. L.L.S. was a member of AstraZeneca advisor board of Olaparib in Pancreatic Cancer. These companies had no role in the decision to publish, nor were they involved in the writing of this manuscript.

\section{References}

1. Pushpakom, S.; Iorio, F.; Eyers, P.A.; Escott, K.J.; Hopper, S.; Wells, A.; Doig, A.; Guilliams, T.; Latimer, J.; McNamee, C.; et al. Drug repurposing: Progress, challenges and recommendations. Nat. Rev. Drug Discov. 2019, 18, 41-58. [CrossRef] [PubMed]

2. Pantziarka, P.; Verbaanderd, C.; Huys, I.; Bouche, G.; Meheus, L. Repurposing drugs in oncology: From candidate selection to clinical adoption. Semin. Cancer Biol. 2020. [CrossRef]

3. Zhang, Z.; Zhou, L.; Xie, N.; Nice, E.C.; Zhang, T.; Cui, Y.; Huang, C. Overcoming cancer therapeutic bottleneck by drug repurposing. Signal. Transduct. Target. Ther. 2020, 5, 113. [CrossRef]

4. Dinic, J.; Efferth, T.; Garcia-Sosa, A.T.; Grahovac, J.; Padron, J.M.; Pajeva, I.; Rizzolio, F.; Saponara, S.; Spengler, G.; Tsakovska, I. Repurposing old drugs to fight multidrug resistant cancers. Drug Resist. Updat. 2020, 52, 100713. [CrossRef]

5. Nosengo, N. Can you teach old drugs new tricks? Nature 2016, 534, 314-316. [CrossRef]

6. Sleire, L.; Forde, H.E.; Netland, I.A.; Leiss, L.; Skeie, B.S.; Enger, P.O. Drug repurposing in cancer. Pharmacol. Res. 2017, 124, 74-91. [CrossRef]

7. Bray, F.; Jemal, A.; Grey, N.; Ferlay, J.; Forman, D. Global cancer transitions according to the Human Development Index (2008-2030): A population-based study. Lancet Oncol. 2012, 13, 790-801. [CrossRef]

8. Scannell, J.W.; Blanckley, A.; Boldon, H.; Warrington, B. Diagnosing the decline in pharmaceutical R\&D efficiency. Nat. Rev. Drug Discov. 2012, 11, 191-200. [CrossRef]

9. Hay, M.; Thomas, D.W.; Craighead, J.L.; Economides, C.; Rosenthal, J. Clinical development success rates for investigational drugs. Nat. Biotechnol. 2014, 32, 40-51. [CrossRef]

10. Hertel, L.W.; Kroin, J.S.; Grossman, C.S.; Grindey, G.B.; Dorr, A.F.; Storniolo, A.M.V.; Plunkett, W.; Gandhi, V.; Huang, P. Synthesis and Biological Activity of 2',2'-Difluorodeoxycytidine (Gemcitabine). In Biomedical Frontiers of Fluorine Chemistry; American Chemical Society: Washington, DC, USA, 1996; Volume 639, pp. 265-278.

11. Ducreux, M.; Cuhna, A.S.; Caramella, C.; Hollebecque, A.; Burtin, P.; Goere, D.; Seufferlein, T.; Haustermans, K.; Van Laethem, J.L.; Conroy, T.; et al. Cancer of the pancreas: ESMO Clinical Practice Guidelines for diagnosis, treatment and follow-up. Ann. Oncol. 2015, 26 (Suppl. 5), v56-v68. [CrossRef]

12. U.S. Food and Drug Administration: Vesanoid. Available online: https://www.accessdata.fda.gov/drugsatfda_docs/label/2004 /20438s004lbl.pdf (accessed on 29 August 2020).

13. European Medicines Agency: IntronA-EMEA/H/C/000281. Available online: https://www.ema.europa.eu/en/documents/ product-information/introna-epar-product-information_en.pdf (accessed on 29 August 2020).

14. Viktorsson, K.; Lewensohn, R.; Zhivotovsky, B. Apoptotic pathways and therapy resistance in human malignancies. Adv. Cancer Res. 2005, 94, 143-196. [CrossRef] [PubMed]

15. U.S. Food and Drug Administration: Evista. Available online: https://www.accessdata.fda.gov/drugsatfda_docs/nda/2007/022 042s000_Lbl.pdf (accessed on 29 August 2020).

16. European Medicines Agency: Abraxane-EMEA/H/C/000778. Available online: https://www.ema.europa.eu/en/documents/ product-information/abraxane-epar-product-information_en.pdf (accessed on 30 August 2020).

17. European Medicines Agency: Imnovid-EMEA/H/C/002682. Available online: https://www.ema.europa.eu/en/documents/ product-information/imnovid-epar-product-information_en.pdf (accessed on 30 August 2020).

18. European Medicines Agency: EMA/475685/2017-Public Summary of Opinion on Orphan Designation. Available online: https://www.ema.europa.eu/en/documents/orphan-designation/eu/3/17/1901-public-summary-opinion-orphandesignation-itraconazole-treatment-naevoid-basal-cell-carcinoma_en.pdf (accessed on 17 February 2021).

19. European Medicines Agency: Lenalidomide Accord-EMEA/H/C/004857. Available online: https://www.ema.europa.eu/en/ documents / product-information/lenalidomide-accord-epar-product-information_en.pdf (accessed on 30 August 2020).

20. European Medicines Agency: Arsenic trioxide Accord-EMEA/H/C/005175. Available online: https:/ /www.ema.europa.eu/ en/documents / product-information/arsenic-trioxide-accord-epar-product-information_en.pdf (accessed on 31 August 2020).

21. WHO-Global Cancer Observatory. Cancer Today: Pancreas. Available online: http:/ /gco.iarc.fr/today/ (accessed on 13 April 2020).

22. Duell, E.J. Epidemiology and potential mechanisms of tobacco smoking and heavy alcohol consumption in pancreatic cancer. Mol. Carcinog. 2012, 51, 40-52. [CrossRef] [PubMed]

23. Arnold, M.; Abnet, C.C.; Neale, R.E.; Vignat, J.; Giovannucci, E.L.; McGlynn, K.A.; Bray, F. Global Burden of 5 Major Types Of Gastrointestinal Cancer. Gastroenterology 2020. [CrossRef]

24. Yachida, S.; Jones, S.; Bozic, I.; Antal, T.; Leary, R.; Fu, B.; Kamiyama, M.; Hruban, R.H.; Eshleman, J.R.; Nowak, M.A.; et al. Distant metastasis occurs late during the genetic evolution of pancreatic cancer. Nature 2010, 467, 1114-1117. [CrossRef]

25. Arnold, M.; Rutherford, M.J.; Bardot, A.; Ferlay, J.; Andersson, T.M.; Myklebust, T.A.; Tervonen, H.; Thursfield, V.; Ransom, D.; Shack, L.; et al. Progress in cancer survival, mortality, and incidence in seven high-income countries 1995-2014 (ICBP SURVMARK-2): A population-based study. Lancet Oncol. 2019, 20, 1493-1505. [CrossRef] 
26. Niederhuber, J.; Armitage, J.; Doroshow, J.; Kastan, M.; Tepper, J. Abeloff's Clinical Oncology, 6th ed.; Elsevier Health Sciences: Amsterdam, The Netherland, 2019.

27. Bosman, F.T.; Carneiro, F.; Hruban, R.H.; Theise, N.D. WHO Classification of Tumours of the Digestive System; World Health Organization: Geneva, Switzerland, 2010.

28. Nagtegaal, I.D.; Odze, R.D.; Klimstra, D.; Paradis, V.; Rugge, M.; Schirmacher, P.; Washington, K.M.; Carneiro, F.; Cree, I.A.; WHO Classification of Tumours Editorial Board. The 2019 WHO classification of tumours of the digestive system. Histopathology 2020, 76, 182-188. [CrossRef]

29. Klimstra, D.S.; Pitman, M.B.; Hruban, R.H. An algorithmic approach to the diagnosis of pancreatic neoplasms. Arch. Pathol. Lab. Med. 2009, 133, 454-464. [CrossRef] [PubMed]

30. Gupta, R.; Amanam, I.; Chung, V. Current and future therapies for advanced pancreatic cancer. J. Surg. Oncol. 2017, 116, 25-34. [CrossRef] [PubMed]

31. Esposito, I.; Konukiewitz, B.; Schlitter, A.M.; Kloppel, G. Pathology of pancreatic ductal adenocarcinoma: Facts, challenges and future developments. World J. Gastroenterol. 2014, 20, 13833-13841. [CrossRef] [PubMed]

32. Hruban, R.H.; Maitra, A.; Kern, S.E.; Goggins, M. Precursors to pancreatic cancer. Gastroenterol. Clin. N. Am. 2007, 36, 831-849. [CrossRef]

33. Scarlett, C.J.; Salisbury, E.L.; Biankin, A.V.; Kench, J. Precursor lesions in pancreatic cancer: Morphological and molecular pathology. Pathology 2011, 43, 183-200. [CrossRef]

34. Morris, J.P.t.; Wang, S.C.; Hebrok, M. KRAS, Hedgehog, Wnt and the twisted developmental biology of pancreatic ductal adenocarcinoma. Nat. Rev. Cancer 2010, 10, 683-695. [CrossRef]

35. Wilentz, R.E.; Iacobuzio-Donahue, C.A.; Argani, P.; McCarthy, D.M.; Parsons, J.L.; Yeo, C.J.; Kern, S.E.; Hruban, R.H. Loss of expression of Dpc4 in pancreatic intraepithelial neoplasia: Evidence that DPC4 inactivation occurs late in neoplastic progression. Cancer Res. 2000, 60, 2002-2006.

36. Maitra, A.; Adsay, N.V.; Argani, P.; Iacobuzio-Donahue, C.; De Marzo, A.; Cameron, J.L.; Yeo, C.J.; Hruban, R.H. Multicomponent analysis of the pancreatic adenocarcinoma progression model using a pancreatic intraepithelial neoplasia tissue microarray. Mod. Pathol. 2003, 16, 902-912. [CrossRef] [PubMed]

37. Notta, F.; Chan-Seng-Yue, M.; Lemire, M.; Li, Y.; Wilson, G.W.; Connor, A.A.; Denroche, R.E.; Liang, S.B.; Brown, A.M.; Kim, J.C.; et al. A renewed model of pancreatic cancer evolution based on genomic rearrangement patterns. Nature 2016, 538, 378-382. [CrossRef] [PubMed]

38. Yabar, C.S.; Winter, J.M. Pancreatic Cancer: A Review. Gastroenterol. Clin. N. Am. 2016, 45, 429-445. [CrossRef] [PubMed]

39. Hidalgo, M. Pancreatic cancer. N. Engl. J. Med. 2010, 362, 1605-1617. [CrossRef]

40. Huang, L.; Jansen, L.; Balavarca, Y.; Babaei, M.; van der Geest, L.; Lemmens, V.; Van Eycken, L.; De Schutter, H.; Johannesen, T.B.; Primic-Zakelj, M.; et al. Stratified survival of resected and overall pancreatic cancer patients in Europe and the USA in the early twenty-first century: A large, international population-based study. BMC Med. 2018, 16, 125. [CrossRef]

41. Katz, M.H.; Fleming, J.B.; Bhosale, P.; Varadhachary, G.; Lee, J.E.; Wolff, R.; Wang, H.; Abbruzzese, J.; Pisters, P.W.; Vauthey, J.N. Response of borderline resectable pancreatic cancer to neoadjuvant therapy is not reflected by radiographic indicators. Cancer 2012, 118, 5749-5756. [CrossRef]

42. Tempero, M.A.; Malafa, M.P.; Al-Hawary, M.; Asbun, H.; Behrman, S.W.; Benson, A.B.; Cardin, D.B.; Cha, C.; Chiorean, E.G.; Chung, V.; et al. NCCN Clinical Practice Guidelines in Oncology (NCCN Guidelines ${ }^{\circledR}$ ): Pancreatic Adenocarcinoma, V 1.2020. J. Natl. Compr. Canc. Netw. 2017, 15, 1028-1061. [CrossRef] [PubMed]

43. Christenson, E.S.; Jaffee, E.; Azad, N.S. Current and emerging therapies for patients with advanced pancreatic ductal adenocarcinoma: A bright future. Lancet Oncol. 2020, 21, e135-e145. [CrossRef]

44. Von Hoff, D.D.; Ervin, T.; Arena, F.P.; Chiorean, E.G.; Infante, J.; Moore, M.; Seay, T.; Tjulandin, S.A.; Ma, W.W.; Saleh, M.N.; et al. Increased survival in pancreatic cancer with nab-paclitaxel plus gemcitabine. N. Engl. J. Med. 2013, 369, 1691-1703. [CrossRef] [PubMed]

45. Wang-Gillam, A.; Li, C.P.; Bodoky, G.; Dean, A.; Shan, Y.S.; Jameson, G.; Macarulla, T.; Lee, K.H.; Cunningham, D.; Blanc, J.F.; et al. Nanoliposomal irinotecan with fluorouracil and folinic acid in metastatic pancreatic cancer after previous gemcitabine-based therapy (NAPOLI-1): A global, randomised, open-label, phase 3 trial. Lancet 2016, 387, 545-557. [CrossRef]

46. Kipps, E.; Young, K.; Starling, N. Liposomal irinotecan in gemcitabine-refractory metastatic pancreatic cancer: Efficacy, safety and place in therapy. Ther. Adv. Med. Oncol. 2017, 9, 159-170. [CrossRef] [PubMed]

47. Uzunparmak, B.; Sahin, I.H. Pancreatic cancer microenvironment: A current dilemma. Clin. Transl. Med. 2019, 8, 2. [CrossRef] [PubMed]

48. Ho, W.J.; Jaffee, E.M.; Zheng, L. The tumour microenvironment in pancreatic cancer-Clinical challenges and opportunities. Nat. Rev. Clin. Oncol. 2020, 17, 527-540. [CrossRef] [PubMed]

49. Whatcott, C.J.; Diep, C.H.; Jiang, P.; Watanabe, A.; LoBello, J.; Sima, C.; Hostetter, G.; Shepard, H.M.; Von Hoff, D.D.; Han, H. Desmoplasia in Primary Tumors and Metastatic Lesions of Pancreatic Cancer. Clin. Cancer Res. 2015, 21, 3561-3568. [CrossRef] [PubMed]

50. Apte, M.V.; Haber, P.S.; Darby, S.J.; Rodgers, S.C.; McCaughan, G.W.; Korsten, M.A.; Pirola, R.C.; Wilson, J.S. Pancreatic stellate cells are activated by proinflammatory cytokines: Implications for pancreatic fibrogenesis. Gut 1999, 44, 534-541. [CrossRef] 
51. Vonlaufen, A.; Joshi, S.; Qu, C.; Phillips, P.A.; Xu, Z.; Parker, N.R.; Toi, C.S.; Pirola, R.C.; Wilson, J.S.; Goldstein, D.; et al. Pancreatic stellate cells: Partners in crime with pancreatic cancer cells. Cancer Res. 2008, 68, 2085-2093. [CrossRef]

52. Neesse, A.; Michl, P.; Frese, K.K.; Feig, C.; Cook, N.; Jacobetz, M.A.; Lolkema, M.P.; Buchholz, M.; Olive, K.P.; Gress, T.M.; et al. Stromal biology and therapy in pancreatic cancer. Gut 2011, 60, 861-868. [CrossRef]

53. Xiao, Q.; Zhou, D.; Rucki, A.A.; Williams, J.; Zhou, J.; Mo, G.; Murphy, A.; Fujiwara, K.; Kleponis, J.; Salman, B.; et al. CancerAssociated Fibroblasts in Pancreatic Cancer Are Reprogrammed by Tumor-Induced Alterations in Genomic DNA Methylation. Cancer Res. 2016, 76, 5395-5404. [CrossRef] [PubMed]

54. Martinez-Useros, J.; Martin-Galan, M.; Garcia-Foncillas, J. The Match between Molecular Subtypes, Histology and Microenvironment of Pancreatic Cancer and Its Relevance for Chemoresistance. Cancers 2021, 13, 322. [CrossRef] [PubMed]

55. Provenzano, P.P.; Cuevas, C.; Chang, A.E.; Goel, V.K.; Von Hoff, D.D.; Hingorani, S.R. Enzymatic targeting of the stroma ablates physical barriers to treatment of pancreatic ductal adenocarcinoma. Cancer Cell 2012, 21, 418-429. [CrossRef]

56. Ohlund, D.; Handly-Santana, A.; Biffi, G.; Elyada, E.; Almeida, A.S.; Ponz-Sarvise, M.; Corbo, V.; Oni, T.E.; Hearn, S.A.; Lee, E.J.; et al. Distinct populations of inflammatory fibroblasts and myofibroblasts in pancreatic cancer. J. Exp. Med. 2017, 214, 579-596. [CrossRef] [PubMed]

57. Chen, C.T.; Chen, Y.C.; Yamaguchi, H.; Hung, M.C. Carglumic acid promotes apoptosis and suppresses cancer cell proliferation in vitro and in vivo. Am. J. Cancer Res. 2015, 5, 3560-3569. [PubMed]

58. Kirane, A.; Ludwig, K.F.; Sorrelle, N.; Haaland, G.; Sandal, T.; Ranaweera, R.; Toombs, J.E.; Wang, M.; Dineen, S.P.; Micklem, D.; et al. Warfarin Blocks Gas6-Mediated Axl Activation Required for Pancreatic Cancer Epithelial Plasticity and Metastasis. Cancer Res. 2015, 75, 3699-3705. [CrossRef] [PubMed]

59. Ocal, O.; Pashkov, V.; Kollipara, R.K.; Zolghadri, Y.; Cruz, V.H.; Hale, M.A.; Heath, B.R.; Artyukhin, A.B.; Christie, A.L.; Tsoulfas, P.; et al. A rapid in vivo screen for pancreatic ductal adenocarcinoma therapeutics. Dis Model. Mech. 2015, 8, 1201-1211. [CrossRef]

60. Tormoen, G.W.; Blair, T.C.; Bambina, S.; Kramer, G.; Baird, J.; Rahmani, R.; Holland, J.M.; McCarty, O.J.T.; Baine, M.J.; Verma, V.; et al. Targeting MerTK Enhances Adaptive Immune Responses After Radiation Therapy. Int. J. Radiat. Oncol. Biol. Phys. 2020, 108, 93-103. [CrossRef] [PubMed]

61. Nakchbandi, W.; Muller, H.; Singer, M.V.; Lohr, M.; Nakchbandi, I.A. Effects of low-dose warfarin and regional chemotherapy on survival in patients with pancreatic carcinoma. Scand. J. Gastroenterol. 2006, 41, 1095-1104. [CrossRef]

62. Candido, S.; Abrams, S.L.; Steelman, L.; Lertpiriyapong, K.; Martelli, A.M.; Cocco, L.; Ratti, S.; Follo, M.Y.; Murata, R.M.; Rosalen, P.L.; et al. Metformin influences drug sensitivity in pancreatic cancer cells. Adv. Biol. Regul. 2018, 68, 13-30. [CrossRef]

63. Chen, K.; Qian, W.; Jiang, Z.; Cheng, L.; Li, J.; Sun, L.; Zhou, C.; Gao, L.; Lei, M.; Yan, B.; et al. Metformin suppresses cancer initiation and progression in genetic mouse models of pancreatic cancer. Mol. Cancer 2017, 16, 131. [CrossRef]

64. Duan, W.; Qian, W.; Zhou, C.; Cao, J.; Qin, T.; Xiao, Y.; Cheng, L.; Li, J.; Chen, K.; Li, X.; et al. Metformin suppresses the invasive ability of pancreatic cancer cells by blocking autocrine TGFbeta1 signaling. Oncol. Rep. 2018, 40, 1495-1502. [CrossRef]

65. Wang, X.; Wu, X.; Zhang, Z.; Ma, C.; Wu, T.; Tang, S.; Zeng, Z.; Huang, S.; Gong, C.; Yuan, C.; et al. Monensin inhibits cell proliferation and tumor growth of chemo-resistant pancreatic cancer cells by targeting the EGFR signaling pathway. Sci. Rep. 2018, 8, 17914. [CrossRef]

66. Veschi, S.; De Lellis, L.; Florio, R.; Lanuti, P.; Massucci, A.; Tinari, N.; De Tursi, M.; di Sebastiano, P.; Marchisio, M.; Natoli, C.; et al. Effects of repurposed drug candidates nitroxoline and nelfinavir as single agents or in combination with erlotinib in pancreatic cancer cells. J. Exp. Clin. Cancer Res. 2018, 37, 236. [CrossRef] [PubMed]

67. Veschi, S.; Ronci, M.; Lanuti, P.; De Lellis, L.; Florio, R.; Bologna, G.; Scotti, L.; Carletti, E.; Brugnoli, F.; Di Bella, M.C.; et al. Integrative proteomic and functional analyses provide novel insights into the action of the repurposed drug candidate nitroxoline in AsPC-1 cells. Sci. Rep. 2020, 10, 2574. [CrossRef]

68. Son, K.; Fujioka, S.; Iida, T.; Furukawa, K.; Fujita, T.; Yamada, H.; Chiao, P.J.; Yanaga, K. Doxycycline induces apoptosis in PANC-1 pancreatic cancer cells. Anticancer Res. 2009, 29, 3995-4003. [PubMed]

69. Lamb, R.; Ozsvari, B.; Lisanti, C.L.; Tanowitz, H.B.; Howell, A.; Martinez-Outschoorn, U.E.; Sotgia, F.; Lisanti, M.P. Antibiotics that target mitochondria effectively eradicate cancer stem cells, across multiple tumor types: Treating cancer like an infectious disease. Oncotarget 2015, 6, 4569. [CrossRef] [PubMed]

70. Batchu, R.B.; Gruzdyn, O.V.; Bryant, C.S.; Qazi, A.M.; Kumar, S.; Chamala, S.; Kung, S.T.; Sanka, R.S.; Puttagunta, U.S.; Weaver, D.W.; et al. Ritonavir-Mediated Induction of Apoptosis in Pancreatic Cancer Occurs via the RB/E2F-1 and AKT Pathways. Pharmaceuticals 2014, 7, 46-57. [CrossRef] [PubMed]

71. O'Donoghue, A.J.; Ivry, S.L.; Chaudhury, C.; Hostetter, D.R.; Hanahan, D.; Craik, C.S. Procathepsin E is highly abundant but minimally active in pancreatic ductal adenocarcinoma tumors. Biol. Chem. 2016, 397, 871-881. [CrossRef]

72. Chen, K.; Cheng, L.; Qian, W.; Jiang, Z.; Sun, L.; Zhao, Y.; Zhou, Y.; Zhao, L.; Wang, P.; Duan, W.; et al. Itraconazole inhibits invasion and migration of pancreatic cancer cells by suppressing TGF-beta/SMAD2/3 signaling. Oncol. Rep. 2018, 39, 1573-1582. [CrossRef]

73. Jiang, F.; Xing, H.S.; Chen, W.Y.; Du, J.; Ruan, Y.L.; Lin, A.Y.; Zhou, C.Z. Itraconazole inhibits proliferation of pancreatic cancer cells through activation of Bak-1. J. Cell Biochem. 2019, 120, 4333-4341. [CrossRef] [PubMed]

74. Florio, R.; Veschi, S.; di Giacomo, V.; Pagotto, S.; Carradori, S.; Verginelli, F.; Cirilli, R.; Casulli, A.; Grassadonia, A.; Tinari, N.; et al. The Benzimidazole-Based Anthelmintic Parbendazole: A Repurposed Drug Candidate That Synergizes with Gemcitabine in Pancreatic Cancer. Cancers 2019, 11, 2042. [CrossRef] [PubMed] 
75. Acedo, P.; Fernandes, A.; Zawacka-Pankau, J. Activation of TAp73 and inhibition of TrxR by Verteporfin for improved cancer therapy in TP53 mutant pancreatic tumors. Future Sci. OA 2019, 5, FSO366. [CrossRef] [PubMed]

76. Li, T.; Guo, T.; Liu, H.; Jiang, H.; Wang, Y. Plateletderived growth factorBB mediates pancreatic cancer malignancy via regulation of the Hippo/Yesassociated protein signaling pathway. Oncol. Rep. 2021, 45, 83-94. [CrossRef]

77. Chien, W.; Sun, Q.Y.; Lee, K.L.; Ding, L.W.; Wuensche, P.; Torres-Fernandez, L.A.; Tan, S.Z.; Tokatly, I.; Zaiden, N.; Poellinger, L.; et al. Activation of protein phosphatase 2A tumor suppressor as potential treatment of pancreatic cancer. Mol. Oncol. 2015, 9, 889-905. [CrossRef] [PubMed]

78. Ranjan, A.; Srivastava, S.K. Penfluridol suppresses pancreatic tumor growth by autophagy-mediated apoptosis. Sci. Rep. 2016, 6, 26165. [CrossRef]

79. Ranjan, A.; German, N.; Mikelis, C.; Srivenugopal, K.; Srivastava, S.K. Penfluridol induces endoplasmic reticulum stress leading to autophagy in pancreatic cancer. Tumour Biol. 2017, 39, 1010428317705517. [CrossRef]

80. Jandaghi, P.; Najafabadi, H.S.; Bauer, A.S.; Papadakis, A.I.; Fassan, M.; Hall, A.; Monast, A.; von Knebel Doeberitz, M.; Neoptolemos, J.P.; Costello, E.; et al. Expression of DRD2 Is Increased in Human Pancreatic Ductal Adenocarcinoma and Inhibitors Slow Tumor Growth in Mice. Gastroenterology 2016, 151, 1218-1231. [CrossRef]

81. Huang, C.; Lan, W.; Fraunhoffer, N.; Meilerman, A.; Iovanna, J.; Santofimia-Castano, P. Dissecting the Anticancer Mechanism of Trifluoperazine on Pancreatic Ductal Adenocarcinoma. Cancers 2019, 11, 1869. [CrossRef]

82. Sanomachi, T.; Suzuki, S.; Kuramoto, K.; Takeda, H.; Sakaki, H.; Togashi, K.; Seino, S.; Yoshioka, T.; Okada, M.; Kitanaka, C. Olanzapine, an Atypical Antipsychotic, Inhibits Survivin Expression and Sensitizes Cancer Cells to Chemotherapeutic Agents. Anticancer Res. 2017, 37, 6177-6188. [CrossRef]

83. Zhang, X.; Hu, P.; Ding, S.Y.; Sun, T.; Liu, L.; Han, S.; DeLeo, A.B.; Sadagopan, A.; Guo, W.; Wang, X. Induction of autophagydependent apoptosis in cancer cells through activation of ER stress: An uncovered anti-cancer mechanism by anti-alcoholism drug disulfiram. Am. J. Cancer Res. 2019, 9, 1266-1281. [PubMed]

84. Cong, J.; Wang, Y.; Zhang, X.; Zhang, N.; Liu, L.; Soukup, K.; Michelakos, T.; Hong, T.; DeLeo, A.; Cai, L.; et al. A novel chemoradiation targeting stem and nonstem pancreatic cancer cells by repurposing disulfiram. Cancer Lett. 2017, 409, 9-19. [CrossRef]

85. Wu, X.; Cao, Y.; Xiao, H.; Li, C.; Lin, J. Bazedoxifene as a Novel GP130 Inhibitor for Pancreatic Cancer Therapy. Mol. Cancer Ther. 2016, 15, 2609-2619. [CrossRef] [PubMed]

86. Masso-Valles, D.; Jauset, T.; Serrano, E.; Sodir, N.M.; Pedersen, K.; Affara, N.I.; Whitfield, J.R.; Beaulieu, M.E.; Evan, G.I.; Elias, L.; et al. Ibrutinib exerts potent antifibrotic and antitumor activities in mouse models of pancreatic adenocarcinoma. Cancer Res. 2015, 75, 1675-1681. [CrossRef]

87. Overman, M.; Javle, M.; Davis, R.E.; Vats, P.; Kumar-Sinha, C.; Xiao, L.; Mettu, N.B.; Parra, E.R.; Benson, A.B.; Lopez, C.D.; et al. Randomized phase II study of the Bruton tyrosine kinase inhibitor acalabrutinib, alone or with pembrolizumab in patients with advanced pancreatic cancer. J. Immunother. Cancer 2020, 8. [CrossRef]

88. Gunderson, A.J.; Kaneda, M.M.; Tsujikawa, T.; Nguyen, A.V.; Affara, N.I.; Ruffell, B.; Gorjestani, S.; Liudahl, S.M.; Truitt, M.; Olson, P.; et al. Bruton Tyrosine Kinase-Dependent Immune Cell Cross-talk Drives Pancreas Cancer. Cancer Discov. 2016, 6, 270-285. [CrossRef] [PubMed]

89. Diop-Frimpong, B.; Chauhan, V.P.; Krane, S.; Boucher, Y.; Jain, R.K. Losartan inhibits collagen I synthesis and improves the distribution and efficacy of nanotherapeutics in tumors. Proc. Natl. Acad. Sci. USA 2011, 108, 2909-2914. [CrossRef]

90. Kim, J.H.; Shin, B.C.; Park, W.S.; Lee, J.; Kuh, H.J. Antifibrotic effects of pentoxifylline improve the efficacy of gemcitabine in human pancreatic tumor xenografts. Cancer Sci. 2017, 108, 2470-2477. [CrossRef]

91. Xavier, C.P.R.; Castro, I.; Caires, H.R.; Ferreira, D.; Cavadas, B.; Pereira, L.; Santos, L.L.; Oliveira, M.J.; Vasconcelos, M.H. Chitinase 3-like-1 and fibronectin in the cargo of extracellular vesicles shed by human macrophages influence pancreatic cancer cellular response to gemcitabine. Cancer Lett. 2021, 501, 210-223. [CrossRef]

92. Kozono, S.; Ohuchida, K.; Eguchi, D.; Ikenaga, N.; Fujiwara, K.; Cui, L.; Mizumoto, K.; Tanaka, M. Pirfenidone inhibits pancreatic cancer desmoplasia by regulating stellate cells. Cancer Res. 2013, 73, 2345-2356. [CrossRef]

93. Usugi, E.; Ishii, K.; Hirokawa, Y.; Kanayama, K.; Matsuda, C.; Uchida, K.; Shiraishi, T.; Watanabe, M. Antifibrotic Agent Pirfenidone Suppresses Proliferation of Human Pancreatic Cancer Cells by Inducing G0/G1 Cell Cycle Arrest. Pharmacology 2019, 103, 250-256. [CrossRef]

94. Food and Drug Administration (FDA). GLUCOPHAGE ${ }^{\circledR}$ (metformin hydrochloride) Tablets. GLUCOPHAGE ${ }^{\circledR}$ XR (metformin hydrochloride) Extended-Release Tablets. Label. 2017. Available online: https:/ /www.accessdata.fda.gov /drugsatfda_docs / label/2017/020357s037s039,021202s021s023lbl.pdf (accessed on 12 January 2021).

95. Li, X.; Li, T.; Liu, Z.; Gou, S.; Wang, C. The effect of metformin on survival of patients with pancreatic cancer: A meta-analysis. Sci. Rep. 2017, 7, 5825. [CrossRef]

96. Mao, Y.; Tao, M.; Jia, X.; Xu, H.; Chen, K.; Tang, H.; Li, D. Effect of Diabetes Mellitus on Survival in Patients with Pancreatic Cancer: A Systematic Review and Meta-analysis. Sci. Rep. 2015, 5, 17102. [CrossRef] [PubMed]

97. Bowker, S.L.; Majumdar, S.R.; Veugelers, P.; Johnson, J.A. Increased cancer-related mortality for patients with type 2 diabetes who use sulfonylureas or insulin. Diabetes Care 2006, 29, 254-258. [CrossRef] [PubMed]

98. De Souza, A.; Khawaja, K.I.; Masud, F.; Saif, M.W. Metformin and pancreatic cancer: Is there a role? Cancer Chemother. Pharmacol. 2016, 77, 235-242. [CrossRef] 
99. Sacco, F.; Calderone, A.; Castagnoli, L.; Cesareni, G. The cell-autonomous mechanisms underlying the activity of metformin as an anticancer drug. Br. J. Cancer 2016, 115, 1451-1456. [CrossRef] [PubMed]

100. Wynn, A.; Vacheron, A.; Zuber, J.; Solomon, S.S. Metformin Associated with Increased Survival in Type 2 Diabetes Patients with Pancreatic Cancer and Lymphoma. Am. J. Med. Sci. 2019, 358, 200-203. [CrossRef] [PubMed]

101. Kordes, S.; Pollak, M.N.; Zwinderman, A.H.; Mathot, R.A.; Weterman, M.J.; Beeker, A.; Punt, C.J.; Richel, D.J.; Wilmink, J.W. Metformin in patients with advanced pancreatic cancer: A double-blind, randomised, placebo-controlled phase 2 trial. Lancet Oncol. 2015, 16, 839-847. [CrossRef]

102. Dong, Y.W.; Shi, Y.Q.; He, L.W.; Cui, X.Y.; Su, P.Z. Effects of metformin on survival outcomes of pancreatic cancer: A meta-analysis. Oncotarget 2017, 8, 55478-55488. [CrossRef]

103. Kesh, K.; Mendez, R.; Abdelrahman, L.; Banerjee, S.; Banerjee, S. Type 2 diabetes induced microbiome dysbiosis is associated with therapy resistance in pancreatic adenocarcinoma. Microb. Cell Fact. 2020, 19, 75. [CrossRef]

104. Shrader, H.R.; Miller, A.M.; Tomanek-Chalkley, A.; McCarthy, A.; Coleman, K.L.; Ear, P.H.; Mangalam, A.K.; Salem, A.K.; Chan, C.H.F. Effect of bacterial contamination in bile on pancreatic cancer cell survival. Surgery 2021, 169, 617-622. [CrossRef] [PubMed]

105. Fan, X.; Alekseyenko, A.V.; Wu, J.; Peters, B.A.; Jacobs, E.J.; Gapstur, S.M.; Purdue, M.P.; Abnet, C.C.; Stolzenberg-Solomon, R.; Miller, G.; et al. Human oral microbiome and prospective risk for pancreatic cancer: A population-based nested case-control study. Gut 2018, 67, 120-127. [CrossRef] [PubMed]

106. Pushalkar, S.; Hundeyin, M.; Daley, D.; Zambirinis, C.P.; Kurz, E.; Mishra, A.; Mohan, N.; Aykut, B.; Usyk, M.; Torres, L.E.; et al. The Pancreatic Cancer Microbiome Promotes Oncogenesis by Induction of Innate and Adaptive Immune Suppression. Cancer Discov. 2018, 8, 403-416. [CrossRef] [PubMed]

107. Thomas, R.M.; Gharaibeh, R.Z.; Gauthier, J.; Beveridge, M.; Pope, J.L.; Guijarro, M.V.; Yu, Q.; He, Z.; Ohland, C.; Newsome, R.; et al. Intestinal microbiota enhances pancreatic carcinogenesis in preclinical models. Carcinogenesis 2018, 39, 1068-1078. [CrossRef] [PubMed]

108. Riquelme, E.; Zhang, Y.; Zhang, L.; Montiel, M.; Zoltan, M.; Dong, W.; Quesada, P.; Sahin, I.; Chandra, V.; San Lucas, A.; et al. Tumor Microbiome Diversity and Composition Influence Pancreatic Cancer Outcomes. Cell 2019, 178, 795-806.e12. [CrossRef]

109. Ciernikova, S.; Novisedlakova, M.; Cholujova, D.; Stevurkova, V.; Mego, M. The Emerging Role of Microbiota and Microbiome in Pancreatic Ductal Adenocarcinoma. Biomedicines 2020, 8, 565. [CrossRef] [PubMed]

110. Shin, N.R.; Lee, J.C.; Lee, H.Y.; Kim, M.S.; Whon, T.W.; Lee, M.S.; Bae, J.W. An increase in the Akkermansia spp. population induced by metformin treatment improves glucose homeostasis in diet-induced obese mice. Gut 2014, 63, 727-735. [CrossRef]

111. Forslund, K.; Hildebrand, F.; Nielsen, T.; Falony, G.; Le Chatelier, E.; Sunagawa, S.; Prifti, E.; Vieira-Silva, S.; Gudmundsdottir, V.; Pedersen, H.K.; et al. Disentangling type 2 diabetes and metformin treatment signatures in the human gut microbiota. Nature 2015, 528, 262-266. [CrossRef]

112. Napolitano, A.; Miller, S.; Nicholls, A.W.; Baker, D.; Van Horn, S.; Thomas, E.; Rajpal, D.; Spivak, A.; Brown, J.R.; Nunez, D.J. Novel gut-based pharmacology of metformin in patients with type 2 diabetes mellitus. PLoS ONE 2014, 9, e100778. [CrossRef]

113. Dong, T.S.; Chang, H.H.; Hauer, M.; Lagishetty, V.; Katzka, W.; Rozengurt, E.; Jacobs, J.P.; Eibl, G. Metformin alters the duodenal microbiome and decreases the incidence of pancreatic ductal adenocarcinoma promoted by diet-induced obesity. Am. J. Physiol. Gastrointest. Liver Physiol. 2019, 317, G763-G772. [CrossRef] [PubMed]

114. European Medicines Agency: Kexxtone-EMEA/V/C/002235. Available online: https://www.ema.europa.eu/en/documents/ product-information/kexxtone-epar-product-information_en.pdf (accessed on 2 February 2021).

115. Wilson, J.M.; Fokas, E.; Dutton, S.J.; Patel, N.; Hawkins, M.A.; Eccles, C.; Chu, K.Y.; Durrant, L.; Abraham, A.G.; Partridge, M.; et al. ARCII: A phase II trial of the HIV protease inhibitor Nelfinavir in combination with chemoradiation for locally advanced inoperable pancreatic cancer. Radiother. Oncol. 2016, 119, 306-311. [CrossRef]

116. Al-Assar, O.; Bittner, M.I.; Lunardi, S.; Stratford, M.R.; McKenna, W.G.; Brunner, T.B. The radiosensitizing effects of Nelfinavir on pancreatic cancer with and without pancreatic stellate cells. Radiother. Oncol. 2016, 119, 300-305. [CrossRef] [PubMed]

117. Brunner, T.B.; Geiger, M.; Grabenbauer, G.G.; Lang-Welzenbach, M.; Mantoni, T.S.; Cavallaro, A.; Sauer, R.; Hohenberger, W.; McKenna, W.G. Phase I trial of the human immunodeficiency virus protease inhibitor nelfinavir and chemoradiation for locally advanced pancreatic cancer. J. Clin. Oncol. 2008, 26, 2699-2706. [CrossRef]

118. Shim, J.S.; Liu, J.O. Recent advances in drug repositioning for the discovery of new anticancer drugs. Int. J. Biol. Sci. 2014, 10, 654-663. [CrossRef] [PubMed]

119. Zimorski, V.; Ku, C.; Martin, W.F.; Gould, S.B. Endosymbiotic theory for organelle origins. Curr. Opin. Microbiol 2014, $22,38-48$. [CrossRef] [PubMed]

120. Aminzadeh-Gohari, S.; Weber, D.D.; Vidali, S.; Catalano, L.; Kofler, B.; Feichtinger, R.G. From old to new-Repurposing drugs to target mitochondrial energy metabolism in cancer. Semin. Cell Dev. Biol. 2020, 98, 211-223. [CrossRef]

121. Nunes, M.; Henriques Abreu, M.; Bartosch, C.; Ricardo, S. Recycling the Purpose of Old Drugs to Treat Ovarian Cancer. Int. J. Mol. Sci. 2020, 21, 7768. [CrossRef]

122. Olive, K.P.; Jacobetz, M.A.; Davidson, C.J.; Gopinathan, A.; McIntyre, D.; Honess, D.; Madhu, B.; Goldgraben, M.A.; Caldwell, M.E.; Allard, D.; et al. Inhibition of Hedgehog signaling enhances delivery of chemotherapy in a mouse model of pancreatic cancer. Science 2009, 324, 1457-1461. [CrossRef] 
123. Thayer, S.P.; di Magliano, M.P.; Heiser, P.W.; Nielsen, C.M.; Roberts, D.J.; Lauwers, G.Y.; Qi, Y.P.; Gysin, S.; Fernandez-del Castillo, C.; Yajnik, V.; et al. Hedgehog is an early and late mediator of pancreatic cancer tumorigenesis. Nature 2003, 425, 851-856. [CrossRef]

124. Jones, S.; Zhang, X.; Parsons, D.W.; Lin, J.C.; Leary, R.J.; Angenendt, P.; Mankoo, P.; Carter, H.; Kamiyama, H.; Jimeno, A.; et al. Core signaling pathways in human pancreatic cancers revealed by global genomic analyses. Science 2008, 321, 1801-1806. [CrossRef]

125. Tsubamoto, H.; Ueda, T.; Inoue, K.; Sakata, K.; Shibahara, H.; Sonoda, T. Repurposing itraconazole as an anticancer agent. Oncol. Lett. 2017, 14, 1240-1246. [CrossRef]

126. Wang, E.J.; Lew, K.; Casciano, C.N.; Clement, R.P.; Johnson, W.W. Interaction of common azole antifungals with P glycoprotein. Antimicrob. Agents Chemother. 2002, 46, 160-165. [CrossRef]

127. Tsubamoto, H.; Sonoda, T.; Ikuta, S.; Tani, S.; Inoue, K.; Yamanaka, N. Combination Chemotherapy with Itraconazole for Treating Metastatic Pancreatic Cancer in the Second-line or Additional Setting. Anticancer Res. 2015, 35, 4191-4196.

128. Lockhart, N.R.; Waddell, J.A.; Schrock, N.E. Itraconazole therapy in a pancreatic adenocarcinoma patient: A case report. J. Oncol. Pharm. Pract. 2016, 22, 528-532. [CrossRef]

129. Huggett, M.T.; Jermyn, M.; Gillams, A.; Illing, R.; Mosse, S.; Novelli, M.; Kent, E.; Bown, S.G.; Hasan, T.; Pogue, B.W.; et al. Phase I/II study of verteporfin photodynamic therapy in locally advanced pancreatic cancer. Br. J. Cancer 2014, 110, 1698-1704. [CrossRef] [PubMed]

130. Celli, J.P.; Solban, N.; Liang, A.; Pereira, S.P.; Hasan, T. Verteporfin-based photodynamic therapy overcomes gemcitabine insensitivity in a panel of pancreatic cancer cell lines. Lasers Surg. Med. 2011, 43, 565-574. [CrossRef]

131. Lu, J.; Roy, B.; Anderson, M.; Leggett, C.L.; Levy, M.J.; Pogue, B.; Hasan, T.; Wang, K.K. Verteporfin- and sodium porfimermediated photodynamic therapy enhances pancreatic cancer cell death without activating stromal cells in the microenvironment. J. Biomed. Opt. 2019, 24, 1-11. [CrossRef] [PubMed]

132. Agostinis, P.; Berg, K.; Cengel, K.A.; Foster, T.H.; Girotti, A.W.; Gollnick, S.O.; Hahn, S.M.; Hamblin, M.R.; Juzeniene, A.; Kessel, D.; et al. Photodynamic therapy of cancer: An update. CA Cancer J. Clin. 2011, 61, 250-281. [CrossRef] [PubMed]

133. Zawacka-Pankau, J.; Issaeva, N.; Hossain, S.; Pramanik, A.; Selivanova, G.; Podhajska, A.J. Protoporphyrin IX interacts with wild-type p53 protein in vitro and induces cell death of human colon cancer cells in a p53-dependent and -independent manner. J. Biol. Chem. 2007, 282, 2466-2472. [CrossRef]

134. Sebio, A.; Lenz, H.J. Molecular Pathways: Hippo Signaling, a Critical Tumor Suppressor. Clin. Cancer Res. 2015, $21,5002-5007$. [CrossRef]

135. Yang, W.; Yang, S.; Zhang, F.; Cheng, F.; Wang, X.; Rao, J. Influence of the Hippo-YAP signalling pathway on tumor associated macrophages (TAMs) and its implications on cancer immunosuppressive microenvironment. Ann. Transl. Med. 2020, 8, 399. [CrossRef] [PubMed]

136. Rozengurt, E.; Sinnett-Smith, J.; Eibl, G. Yes-associated protein (YAP) in pancreatic cancer: At the epicenter of a targetable signaling network associated with patient survival. Signal. Transduct. Target. Ther. 2018, 3, 11. [CrossRef] [PubMed]

137. Barak, Y.; Achiron, A.; Mandel, M.; Mirecki, I.; Aizenberg, D. Reduced cancer incidence among patients with schizophrenia. Cancer 2005, 104, 2817-2821. [CrossRef] [PubMed]

138. Shaw, V.; Srivastava, S.; Srivastava, S.K. Repurposing antipsychotics of the diphenylbutylpiperidine class for cancer therapy. Semin. Cancer Biol. 2021, 68, 75-83. [CrossRef]

139. Weissenrieder, J.S.; Neighbors, J.D.; Mailman, R.B.; Hohl, R.J. Cancer and the Dopamine D2 Receptor: A Pharmacological Perspective. J. Pharmacol. Exp. Ther. 2019, 370, 111-126. [CrossRef] [PubMed]

140. Jiao, Y.; Hannafon, B.N.; Ding, W.Q. Disulfiram's Anticancer Activity: Evidence and Mechanisms. Anticancer Agents Med. Chem. 2016, 16, 1378-1384. [CrossRef]

141. Chen, D.; Cui, Q.C.; Yang, H.; Dou, Q.P. Disulfiram, a clinically used anti-alcoholism drug and copper-binding agent, induces apoptotic cell death in breast cancer cultures and xenografts via inhibition of the proteasome activity. Cancer Res. 2006, 66, 10425-10433. [CrossRef]

142. Wilmink, H. Metformin Combined with Chemotherapy for Pancreatic Cancer (GEM). Identifier: NCT01210911. Available online: https: / / clinicaltrials.gov / ct2/show / NCT01210911 (accessed on 3 February 2021).

143. Krishnamurthi, S. Metformin Plus Modified FOLFOX 6 in Metastatic Pancreatic Cancer. Identifier: NCT01666730. Available online: https: / / clinicaltrials.gov/ct2/show/NCT01666730 (accessed on 3 February 2021).

144. Reni, M. Combination Chemotherapy with or without Metformin Hydrochloride in Treating Patients with Metastatic Pancreatic Cancer (PACT-17). Identifier: NCT01167738. Available online: https:/ / clinicaltrials.gov/ct2/show/NCT01167738 (accessed on 3 February 2021).

145. Yu, X. Metformin Combined with Gemcitabine as Adjuvant Therapy for Pancreatic Cancer after Curative Resection. Identifier: NCT02005419. Available online: https:/ / clinicaltrials.gov/ct2/show /NCT02005419 (accessed on 10 February 2021).

146. Riechelmann, S.P.R. Treatment of Patients with Advanced Pancreatic Cancer after Gemcitabine Failure. Identifier: NCT01971034. Available online: https:/ / clinicaltrials.gov/ct2/show /NCT01971034 (accessed on 7 February 2021).

147. Braghiroli, M.I.; de Celis Ferrari, A.C.; Pfiffer, T.E.; Alex, A.K.; Nebuloni, D.; Carneiro, A.S.; Caparelli, F.; Senna, L.; Lobo, J.; Hoff, P.M.; et al. Phase II trial of metformin and paclitaxel for patients with gemcitabine-refractory advanced adenocarcinoma of the pancreas. Ecancermedicalscience 2015, 9, 563. [CrossRef] 
148. Food and Drug Administration (FDA). ACTOS (Pioglitazone Hydrochloride) Tablets for Oral Use. Label. 2011. Available online: https://www.accessdata.fda.gov/drugsatfda_docs/label/2011/021073s043s044lbl.pdf (accessed on 3 February 2021).

149. Ninomiya, I.; Yamazaki, K.; Oyama, K.; Hayashi, H.; Tajima, H.; Kitagawa, H.; Fushida, S.; Fujimura, T.; Ohta, T. Pioglitazone inhibits the proliferation and metastasis of human pancreatic cancer cells. Oncol. Lett. 2014, 8, 2709-2714. [CrossRef]

150. Beg, M. A Phase II Study of Pioglitazone for Patients with Cancer of the Pancreas. Identifier: NCT01838317. Available online: https:/ / clinicaltrials.gov/ct2/show/NCT01838317 (accessed on 14 February 2021).

151. Linnell, J.C. VITAMINS I Water-Soluble: Thin-Layer (Planar) Chromatography. In Encyclopedia of Separation Science; Wilson, I.D., Ed.; Academic Press: Oxford, UK, 2000; pp. 4454-4460.

152. Naidu, K.A. Vitamin $C$ in human health and disease is still a mystery? An overview. Nutr. J. 2003, 2, 7. [CrossRef]

153. Polireddy, K.; Dong, R.; Reed, G.; Yu, J.; Chen, P.; Williamson, S.; Violet, P.C.; Pessetto, Z.; Godwin, A.K.; Fan, F.; et al. High Dose Parenteral Ascorbate Inhibited Pancreatic Cancer Growth and Metastasis: Mechanisms and a Phase I/IIa study. Sci. Rep. 2017, 7, 17188. [CrossRef] [PubMed]

154. Hirschfeld, A. Ph 2 Trial of Vitamin C \& G-FLIP (Low Doses Gemcitabine, 5FU, Leucovorin, Irinotecan, Oxaliplatin) for Pancreatic Cancer. Identifier: NCT01905150. Available online: https:/ / clinicaltrials.gov/ct2/show /NCT01905150 (accessed on 20 February 2021).

155. Hirschfeld, A.; Bruckner, H. An open-label phase II trial of G-FLIP (low doses of gemcitabine, 5-FU, leucovorin, irinotecan \& oxaliplatin), followed by G-FLIP-DM (G-FLIP + low doses of docetaxel \& mitomycin C), used concurrently with ascorbic acid (AA), in patients with advanced pancreatic cancer. J. Clin. Oncol. 2016, 34 (Suppl. 15), e15745.

156. Jameson, G.S. Trial of Ascorbic Acid (AA) + Nanoparticle Paclitaxel Protein Bound + Cisplatin + Gemcitabine (AA NABPLAGEM) Identifier: NCT03410030. Available online: https: / clinicaltrials.gov/ct2/show / NCT03410030 (accessed on 3 February 2021).

157. Cullen, J.J. A Phase 2 Trial of High-dose Ascorbate for Pancreatic Cancer (PACMAN 2.1). Identifier: NCT02905578. Available online: https: / / clinicaltrials.gov/ct2/show / NCT02905578 (accessed on 17 February 2021).

158. Zhou, F. High Dose Vitamin C Combined with Metformin in the Treatment of Malignant Tumors. Identifier: NCT04033107. Available online: https:/ / clinicaltrials.gov/ct2/show /NCT04033107 (accessed on 17 February 2021).

159. Cullen, J.J. A Clinical Trial Evaluating the Effect of Pharmacological Ascorbate on Radiation Therapy for Pancreatic Cancer Patients (XACT-PANC-2). Identifier: NCT03541486. Available online: https:/ / clinicaltrials.gov/ct2/show/NCT03541486 (accessed on 17 February 2021).

160. Shah, M. High Dose Vitamin C Intravenous Infusion in Patients with Resectable or Metastatic Solid Tumor Malignancies. Identifier: NCT03146962. Available online: https:/ / clinicaltrials.gov/ct2/show /NCT03146962 (accessed on 17 February 2021).

161. Food and Drug Administration (FDA). ZEMPLAR_Paricalcitol injection. Label. 2011. Available online: https://www.accessdata. fda.gov / drugsatfda_docs/label/2011/020819s025lbl.pdf (accessed on 17 February 2021).

162. Chiang, K.C.; Chen, T.C. Vitamin D for the prevention and treatment of pancreatic cancer. World J. Gastroenterol. 2009, 15, 3349-3354. [CrossRef] [PubMed]

163. Hennessy, B. Paricalcitol Trial. Identifier: NCT04617067. Available online: https:/ clinicaltrials.gov/ct2/show / NCT04617067 (accessed on 18 February 2021).

164. El-Rayes, B.F. Paricalcitol and Hydroxychloroquine in Combination with Gemcitabine and Nab-Paclitaxel for the Treatment of Advanced or Metastatic Pancreatic Cancer. Identifier: NCT04524702. Available online: https://clinicaltrials.gov/ct2/show/ NCT04524702 (accessed on 17 February 2021).

165. Perez, K. Paricalcitol Plus Gemcitabine and Nab-paclitaxel in Metastatic Pancreatic Cancer. Identifier: NCT03520790. Available online: https: / / clinicaltrials.gov / ct2/show / NCT03520790 (accessed on 18 February 2021).

166. National Library of Medicine (U.S.). (29 November 2018). Paricalcitol Addition to Chemotherapy in Patients with Previously Untreated Metastatic Pancreatic Ductal Adenocarcinoma (PINBALL). Identifier: NCT04054362. Available online: https:// clinicaltrials.gov/ct2/show / NCT04054362 (accessed on 18 February 2021).

167. Borazanci, E. Pre-operative Treatment for Patients with Untreated Pancreatic Cancer. Identifier: NCT03138720. Available online: https: / clinicaltrials.gov/ct2/show / NCT03138720 (accessed on 20 February 2021).

168. Borazanci, E. Paclitaxel Protein Bound Plus Cisplatin Plus Gemcitabine and Paricalcitol for Pancreatic Adenocarcinoma (NABPLAGEMD). Identifier: NCT03415854. Available online: https:/ / clinicaltrials.gov/ct2/show / NCT03415854 (accessed on 17 February 2021).

169. Food and Drug Administration (FDA). Aralen ${ }^{\circledR}$ chloroquine Phosphate, Usp. Label. 2013. Available online: https://www. accessdata.fda.gov/drugsatfda_docs/label/2013/006002s043lbl.pdf (accessed on 20 February 2021).

170. Food and Drug Administration (FDA). Hydroxychloroquine Sulfate Tablets. Label. 2017. Available online: https://www. accessdata.fda.gov / drugsatfda_docs/label/2020/040766Orig1s013lbl.pdf (accessed on 20 February 2021).

171. Amaravadi, R.K.; Lippincott-Schwartz, J.; Yin, X.M.; Weiss, W.A.; Takebe, N.; Timmer, W.; DiPaola, R.S.; Lotze, M.T.; White, E. Principles and current strategies for targeting autophagy for cancer treatment. Clin. Cancer Res. 2011, 17, 654-666. [CrossRef]

172. Yang, S.; Wang, X.; Contino, G.; Liesa, M.; Sahin, E.; Ying, H.; Bause, A.; Li, Y.; Stommel, J.M.; Dell'antonio, G.; et al. Pancreatic cancers require autophagy for tumor growth. Genes Dev. 2011, 25, 717-729. [CrossRef]

173. Yang, A.; Rajeshkumar, N.V.; Wang, X.; Yabuuchi, S.; Alexander, B.M.; Chu, G.C.; Von Hoff, D.D.; Maitra, A.; Kimmelman, A.C. Autophagy is critical for pancreatic tumor growth and progression in tumors with p53 alterations. Cancer Discov. 2014, 4, 905-913. [CrossRef] 
174. Hong, T.S. Short Course Radiation Therapy with Proton or Photon Beam Capecitabine and Hydroxychloroquine for Resectable Pancreatic Cancer. Identifier: NCT01494155. Available online: https:/ / linicaltrials.gov/ct2/show /NCT01494155 (accessed on 20 February 2021).

175. O'Dwyer, P. A Phase I/II/Pharmacodynamic Study of Hydroxychloroquine in Combination with Gemcitabine/Abraxane to Inhibit Autophagy in Pancreatic Cancer. Identifier: NCT01506973. Available online: https://clinicaltrials.gov/ct2/show /NCT0 1506973 (accessed on 20 February 2021).

176. Borazanci, E. Phase II Study of Paclitaxel Protein Bound + Gemcitabine + Cisplatin + Hydrochloroquine as Treatment in Untreated Pancreas Cancer. Identifier: NCT04669197. Available online: https:/ / clinicaltrials.gov/ct2/show / NCT04669197 (accessed on 20 February 2021).

177. Samaras, P. Adjuvant Effect of Chloroquine on Gemcitabine. Identifier: NCT01777477. Available online: https://clinicaltrials. gov/ct2/show / NCT01777477 (accessed on 20 February 2021).

178. Samaras, P.; Tusup, M.; Nguyen-Kim, T.D.L.; Seifert, B.; Bachmann, H.; von Moos, R.; Knuth, A.; Pascolo, S. Phase I study of a chloroquine-gemcitabine combination in patients with metastatic or unresectable pancreatic cancer. Cancer Chemother. Pharmacol. 2017, 80, 1005-1012. [CrossRef]

179. National Cancer Institute (NIH). Drugs Approved for Pancreatic Cancer. Available online: https://www.cancer.gov/aboutcancer/treatment/drugs/pancreatic (accessed on 12 February 2021).

180. Food and Drug Administration (FDA). SUTENT (Sunitinib Malate) Label. 2014. Available online: https:/ /www.accessdata.fda. gov/drugsatfda_docs/label/2014/021938s027lbl.pdf (accessed on 22 February 2021).

181. Food and Drug Administration (FDA). TARCEVA (Erlotinib) Label. 2016. Available online: https:/ / www.accessdata.fda.gov/ drugsatfda_docs/label/2016/021743s025lbl.pdf (accessed on 22 February 2021).

182. Food and Drug Administration (FDA). JAKAFI (Ruxolitinib) Label. 2011. Available online: https:/ /www.accessdata.fda.gov/ drugsatfda_docs/label/2011/202192lbl.pdf (accessed on 22 February 2021).

183. Hurwitz, H.I.; Uppal, N.; Wagner, S.A.; Bendell, J.C.; Beck, J.T.; Wade, S.M., 3rd; Nemunaitis, J.J.; Stella, P.J.; Pipas, J.M.; Wainberg, Z.A.; et al. Randomized, Double-Blind, Phase II Study of Ruxolitinib or Placebo in Combination with Capecitabine in Patients with Metastatic Pancreatic Cancer for Whom Therapy with Gemcitabine Has Failed. J. Clin. Oncol. 2015, 33, 4039-4047. [CrossRef]

184. Williams, W. Study of Ruxolitinib in Pancreatic Cancer Patients (RECAP). Identifier: NCT01423604. Available online: https: / / clinicaltrials.gov/ct2/show / NCT01423604 (accessed on 15 February 2021).

185. Dawkins, F. A Study of Ruxolitinib in Pancreatic Cancer Patients. Identifier: NCT02119663. Available online: https://clinicaltrials. gov/ct2/show / NCT02119663 (accessed on 15 February 2021).

186. Dawkins, F. Study of Ruxolitinib in Pancreatic Cancer Patients (Janus 1). Identifier: NCT02117479. Available online: https: / / clinicaltrials.gov / ct2/show / NCT02117479 (accessed on 15 February 2021).

187. Hurwitz, H.; Van Cutsem, E.; Bendell, J.; Hidalgo, M.; Li, C.P.; Salvo, M.G.; Macarulla, T.; Sahai, V.; Sama, A.; Greeno, E.; et al. Ruxolitinib + capecitabine in advanced/metastatic pancreatic cancer after disease progression/intolerance to first-line therapy: JANUS 1 and 2 randomized phase III studies. Investig. New Drugs 2018, 36, 683-695. [CrossRef]

188. European Medicines Agency Veterinary Medicines. European Public Assessment Report (Epar). Masivet. Epar Summary for the Public. 2009. Available online: https:/ / www.ema.europa.eu/en/documents / overview/masivet-epar-summary-public_en.pdf (accessed on 23 February 2021).

189. Deplanque, G. Masitinib in Combination with Gemcitabine for Treatment of Patients with Advanced/Metastatic Pancreatic Cancer. Identifier: NCT00789633. Available online: https: / clinicaltrials.gov/ct2/show / NCT00789633 (accessed on 23 February 2021).

190. Deplanque, G.; Demarchi, M.; Hebbar, M.; Flynn, P.; Melichar, B.; Atkins, J.; Nowara, E.; Moye, L.; Piquemal, D.; Ritter, D.; et al. A randomized, placebo-controlled phase III trial of masitinib plus gemcitabine in the treatment of advanced pancreatic cancer. Ann. Oncol. 2015, 26, 1194-1200. [CrossRef]

191. Global News Wire. AB Science Announces that Confirmatory Phase 3 Study AB12005 with Masitinib in First Line Pancreatic Cancer with Pain Was Successful and Reached Its Primary Objective to Show Statistically Significant Increase in Survival. Available online: https:/ / ml-eu.globenewswire.com/Resource/Download/81844e46-c8a2-4124-9d98-8e8a5877e71f (accessed on 21 February 2021).

192. Ezenfis, J. Masitinib Plus Gemcitabine in Pancreatic Cancer. Identifier: NCT03766295. Available online: https:/ /clinicaltrials.gov / ct2/show/NCT03766295 (accessed on 21 February 2021).

193. Food and Drug Administration (FDA). NEXAVAR (Sorafenib) Label. 2018. Available online: https://www.accessdata.fda.gov/ drugsatfda_docs/label/2018/021923s0201bl.pdf (accessed on 20 February 2021).

194. Wilhelm, S.M.; Carter, C.; Tang, L.; Wilkie, D.; McNabola, A.; Rong, H.; Chen, C.; Zhang, X.; Vincent, P.; McHugh, M.; et al. BAY 43-9006 exhibits broad spectrum oral antitumor activity and targets the RAF/MEK/ERK pathway and receptor tyrosine kinases involved in tumor progression and angiogenesis. Cancer Res. 2004, 64, 7099-7109. [CrossRef]

195. Viret, F. Gemcitabine with or without Sorafenib in Treating Patients with Locally Advanced or Metastatic Pancreatic Cancer. Identifier: NCT00541021. Available online: https:/ / clinicaltrials.gov/ct2/show / NCT00541021 (accessed on 24 February 2021).

196. Goncalves, A.; Gilabert, M.; Francois, E.; Dahan, L.; Perrier, H.; Lamy, R.; Re, D.; Largillier, R.; Gasmi, M.; Tchiknavorian, X.; et al BAYPAN study: A double-blind phase III randomized trial comparing gemcitabine plus sorafenib and gemcitabine plus placebo in patients with advanced pancreatic cancer. Ann. Oncol. 2012, 23, 2799-2805. [CrossRef] 
197. Chen, A. PARP inhibitors: Its role in treatment of cancer. Chin. J. Cancer 2011, 30, 463-471. [CrossRef]

198. Ame, J.C.; Spenlehauer, C.; de Murcia, G. The PARP Superfamily. Bioessays 2004, 26, 882-893. [CrossRef] [PubMed]

199. Kwok, K.K.; Vincent, E.C.; Gibson, J.N. 36-Antineoplastic Drugs. In Pharmacology and Therapeutics for Dentistry, 7th ed.; Dowd, F.J., Johnson, B.S., Mariotti, A.J., Eds.; Mosby: Maryland Heights, MI, USA, 2017; pp. 530-562.

200. Food and Drug Administration (FDA). LYNPARZA (Olaparib) Label. 2018. Available online: https://www.accessdata.fda.gov/ drugsatfda_docs/label/2018/208558s001lbl.pdf (accessed on 24 February 2021).

201. Golan, T.; Hammel, P.; Reni, M.; Van Cutsem, E.; Macarulla, T.; Hall, M.J.; Park, J.O.; Hochhauser, D.; Arnold, D.; Oh, D.Y.; et al. Maintenance Olaparib for Germline BRCA-Mutated Metastatic Pancreatic Cancer. N. Engl. J. Med. 2019, 381, 317-327. [CrossRef]

202. CancerNetwork. FDA Approves First PARP Inhibitor as Frontline Maintenance in Pancreatic Cancer. 2019. Available online: https: / / www.cancernetwork.com/view / fda-approves-first-parp-inhibitor-frontline-maintenance-pancreatic-cancer (accessed on 17 February 2021).

203. Food and Drug Administration (FDA). ZEJULA (Niraparib) Label. 2020. Available online: https:/ / www.accessdata.fda.gov / drugsatfda_docs/label/2020/208447s015s017lbledt.pdf (accessed on 24 February 2021).

204. Kasi, A. Niraparib in Metastatic Pancreatic Cancer After Previous Chemotherapy (NIRA-PANC): A Phase 2 Trial (NIRA-PANC). Identifier: NCT03553004. Available online: https:/ / clinicaltrials.gov/ct2/show/NCT03553004 (accessed on 24 February 2021).

205. Niraparib in Patients with Pancreatic Cancer. Identifier: NCT03601923. Available online: https://clinicaltrials.gov/ct2/show / NCT03601923 (accessed on 24 February 2021).

206. Food and Drug Administration (FDA). RUBRACA®(Rucaparib) Label. 2020. Available online: https://www.accessdata.fda.gov / drugsatfda_docs/label/2020/209115s004lbl.pdf (accessed on 24 February 2021).

207. Shroff, R.T.; Hendifar, A.; McWilliams, R.R.; Geva, R.; Epelbaum, R.; Rolfe, L.; Goble, S.; Lin, K.K.; Biankin, A.V.; Giordano, H.; et al. Rucaparib Monotherapy in Patients with Pancreatic Cancer and a Known Deleterious BRCA Mutation. JCO Precis. Oncol. 2018, 2018. [CrossRef]

208. Giordano, H. A Study of Rucaparib in Patients with Pancreatic Cancer and a Known Deleterious BRCA Mutation. Identifier: NCT02042378. Available online: https:/ / clinicaltrials.gov/ct2/show / NCT02042378 (accessed on 24 February 2021).

209. Binder, K.R. Maintenance Rucaparib in BRCA1, BRCA2 or PALB2 Mutated Pancreatic Cancer That Has Not Progressed on Platinum-Based Therapy. Identifier: NCT03140670. Available online: https://clinicaltrials.gov/ct2/show/NCT03140670 (accessed on 24 February 2021).

210. Food and Drug Administration (FDA). AVASTIN (Bevacizumab) Label. 2013. Available online: https: / /www.accessdata.fda. gov /drugsatfda_docs/label/2014/125085s3011bl.pdf (accessed on 24 February 2021).

211. National Library of Medicine (U.S.). A Study of Avastin (Bevacizumab) Added to a Chemotherapeutic Regimen in Patients with Metastatic Pancreatic Cancer. Identifier: NCT01214720. Available online: https:/ / clinicaltrials.gov/ct2/show/NCT01214720 (accessed on 23 February 2021).

212. Van Cutsem, E.; Vervenne, W.L.; Bennouna, J.; Humblet, Y.; Gill, S.; Van Laethem, J.L.; Verslype, C.; Scheithauer, W.; Shang, A.; Cosaert, J.; et al. Phase III trial of bevacizumab in combination with gemcitabine and erlotinib in patients with metastatic pancreatic cancer. J. Clin. Oncol. 2009, 27, 2231-2237. [CrossRef] [PubMed]

213. Kindler, H. Gemcitabine with or without Bevacizumab in Treating Patients with Locally Advanced or Metastatic Pancreatic Cancer. Identifier: NCT00088894. Available online: https:/ / clinicaltrials.gov/ct2/show / NCT00088894 (accessed on 24 February 2021).

214. Kindler, H.L.; Niedzwiecki, D.; Hollis, D.; Sutherland, S.; Schrag, D.; Hurwitz, H.; Innocenti, F.; Mulcahy, M.F.; O’Reilly, E.; Wozniak, T.F.; et al. Gemcitabine plus bevacizumab compared with gemcitabine plus placebo in patients with advanced pancreatic cancer: Phase III trial of the Cancer and Leukemia Group B (CALGB 80303). J. Clin. Oncol. 2010, 28, 3617-3622. [CrossRef] [PubMed]

215. National Library of Medicine (U.S.). A Study of Multiple Immunotherapy-Based Treatment Combinations in Participants with Metastatic Pancreatic Ductal Adenocarcinoma (Morpheus-Pancreatic Cancer). Identifier: NCT03193190. Available online: https: / / clinicaltrials.gov / ct2/show / NCT03193190 (accessed on 25 February 2021).

216. National Library of Medicine (U.S.). Two Chemotherapy Regimens Plus or Minus Bevacizumab (BETTER 2). Identifier: NCT03351296. Available online: https: / / clinicaltrials.gov/ct2/show/NCT03351296 (accessed on 25 February 2021).

217. Food and Drug Administration (FDA). ERBITUX (Cetuximab) Label. 2019. Available online: https://www.accessdata.fda.gov / drugsatfda_docs/label/2019/125084s273lbl.pdf (accessed on 26 February 2021).

218. Philip, A.; O'Reilly, E.; Wong, R. S0205 Gemcitabine w/ or w/o Cetuximab as First-Line Therapy in Locally Advanced Pancreas Cancer. Identifier: NCT00075686. Available online: https:/ / clinicaltrials.gov/ct2/show / NCT00075686 (accessed on 27 February 2021).

219. Philip, P.A.; Benedetti, J.; Corless, C.L.; Wong, R.; O’Reilly, E.M.; Flynn, P.J.; Rowland, K.M.; Atkins, J.N.; Mirtsching, B.C.; Rivkin, S.E.; et al. Phase III study comparing gemcitabine plus cetuximab versus gemcitabine in patients with advanced pancreatic adenocarcinoma: Southwest Oncology Group-directed intergroup trial S0205. J. Clin. Oncol. 2010, 28, 3605-3610. [CrossRef] [PubMed]

220. Food and Drug Administration (FDA). EYLEA®(Aflibercept) Label. 2019. Available online: https:/ /www.accessdata.fda.gov / drugsatfda_docs/label/2019/125387s061lbl.pdf (accessed on 22 February 2021). 
221. National Library of Medicine (U.S.). (December 2007-November 2010). Aflibercept Compared to Placebo in Term of Efficacy in Patients Treated with Gemcitabine for Metastatic Pancreatic Cancer (VANILLA). Identifier: NCT00574275. Available online: https:/ / clinicaltrials.gov/ct2/show / NCT00574275 (accessed on 22 February 2021).

222. Rougier, P.; Riess, H.; Manges, R.; Karasek, P.; Humblet, Y.; Barone, C.; Santoro, A.; Assadourian, S.; Hatteville, L.; Philip, P.A. Randomised, placebo-controlled, double-blind, parallel-group phase III study evaluating aflibercept in patients receiving first-line treatment with gemcitabine for metastatic pancreatic cancer. Eur J. Cancer 2013, 49, 2633-2642. [CrossRef] [PubMed]

223. Food and Drug Administration (FDA). CELEBREX ®(celecoxib) Label. 2018. Available online: https://www.accessdata.fda.gov/ drugsatfda_docs/label/2018/020998s0501bl.pdf (accessed on 22 February 2021).

224. Tucker, O.N.; Dannenberg, A.J.; Yang, E.K.; Zhang, F.; Teng, L.; Daly, J.M.; Soslow, R.A.; Masferrer, J.L.; Woerner, B.M.; Koki, A.T.; et al. Cyclooxygenase-2 expression is up-regulated in human pancreatic cancer. Cancer Res. 1999, 59, 987-990.

225. Xiong, H.Q. Gemcitabine and Celecoxib in Treating Patients with Metastatic Pancreatic Cancer. Identifier: NCT00068432. Available online: https:/ / clinicaltrials.gov/ct2/show /NCT00068432 (accessed on 22 February 2021).

226. Zalupski, M. Gemcitabine, Cisplatin, and Celecoxib Treatment of Metastatic Pancreatic Cancer. Identifier: NCT00176813. Available online: https: / / clinicaltrials.gov/ct2/show / NCT00176813 (accessed on 22 February 2021).

227. Kobrossy, B.; El-Rayes, B.F.; Shields, A.F.; Vaishampayan, U.; Heilbrun, L.; Zalupski, M.M.; Philip, P.A. A phase II study of gemcitabine by fixed-dose rate infusion, cisplatin, and celecoxib in metastatic pancreatic cancer. J. Clin. Oncol. 2004, 22 (Suppl. 14), 4120. [CrossRef]

228. Dragovich, T.; Burris, H., 3rd; Loehrer, P.; Von Hoff, D.D.; Chow, S.; Stratton, S.; Green, S.; Obregon, Y.; Alvarez, I.; Gordon, M. Gemcitabine plus celecoxib in patients with advanced or metastatic pancreatic adenocarcinoma: Results of a phase II trial. Am. J. Clin. Oncol. 2008, 31, 157-162. [CrossRef] [PubMed]

229. Nadir, A. Phase III Trial of Gemcitabine, Curcumin and Celebrex in Patients with Advance or Inoperable Pancreatic Cancer. Identifier: NCT00486460. Available online: https: / /www.clinicaltrials.gov/ct2/show / NCT00486460term=celecoxib\&cond= Pancreatic + Cancer $\&$ phase $=123 \&$ draw $=2 \&$ rank $=5$ (accessed on 25 February 2021).

230. Ho-Seong, H. Cyclooxygenase-2 Inhibitor for Adjuvant Anticancer Effect in Patients with Biliary-pancreas Cancer. Identifier: NCT01111591. Available online: https:/ / www.clinicaltrials.gov/ct2/show /NCT01111591?term=celecoxib\&cond=Pancreatic+ Cancer\&phase $=123 \&$ draw $=2 \&$ rank $=4$ (accessed on 25 February 2021).

231. National Library of Medicine (U.S.). Gemcitabine and Celecoxib Combination Therapy in Treating Patients with R0 Resection Pancreatic Cancer (GCRP). Identifier: NCT03498326. Available online: https:/ / www.clinicaltrials.gov/ct2/show/NCT03498326? term $=$ celecoxib\&cond=Pancreatic + Cancer $\&$ phase $=123 \&$ draw $=2 \&$ rank $=2$ (accessed on 25 February 2021).

232. Kayaleh, O. Tolfenamic Acid, Gemcitabine and Radiation for Locally Advanced or Metastatic Pancreatic Cancer Requiring Radiation. Identifier: NCT02159248. Available online: https:/ / www.clinicaltrials.gov/ct2/show/NCT02159248?term=tolfenamic+ acid\&cond=pancreatic + cancer\&draw $=2 \&$ rank $=1$ (accessed on 25 February 2021).

233. Food and Drug Administration (FDA). COZAAR®(losartan potassium) Label. 2018. Available online: https:/ /www.accessdata fda.gov / drugsatfda_docs/label/2018/020386s062lbl.pdf (accessed on 28 February 2021).

234. Hong, T. Proton w /FOLFIRINOX-Losartan for Pancreatic Cancer. Identifier: NCT01821729. Available online: https: / clinicaltrials. gov/ct2/show / NCT01821729 (accessed on 28 February 2021).

235. Murphy, J.E.; Wo, J.Y.; Ryan, D.P.; Clark, J.W.; Jiang, W.; Yeap, B.Y.; Drapek, L.C.; Ly, L.; Baglini, C.V.; Blaszkowsky, L.S.; et al. Total Neoadjuvant Therapy with FOLFIRINOX in Combination with Losartan Followed by Chemoradiotherapy for Locally Advanced Pancreatic Cancer: A Phase 2 Clinical Trial. JAMA Oncol. 2019, 5, 1020-1027. [CrossRef] [PubMed]

236. Lloyd, S. Losartan and Hypofractionated Rx After Chemo for Tx of Borderline Resectable or Locally Advanced Unresectable Pancreatic Cancer (SHAPER). Identifier: NCT04106856. Available online: https:/ / clinicaltrials.gov/ct2/show/NCT04106856 (accessed on 28 February 2021).

237. Hong, T.S. Losartan and Nivolumab in Combination with FOLFIRINOX and SBRT in Localized Pancreatic Cancer. Identifier: NCT03563248. Available online: https:/ / clinicaltrials.gov/ct2/show /NCT03563248 (accessed on 28 February 2021).

238. Lopez Charles, D. NeoOPTIMIZE: Early Switching of mFOLFIRINOX or Gemcitabine/Nab-Paclitaxel Before Surgery for the Treatment of Resectable or Borderline Resectable Pancreatic Cancer. Identifier: NCT04539808. Available online: https: / / clinicaltrials.gov/ct2/show / NCT04539808 (accessed on 28 February 2021). 